\title{
CHALLENGING COMPLIANCE WITH INTERNATIONAL INTELLECTUAL PROPERTY NORMS IN INVESTOR-STATE DISPUTE SETTLEMENT
}

\author{
Henning Grosse Ruse - Khan*
}

(forthcoming in the Journal of International Economic Law, 2016, No.1)

\begin{abstract}
Enforcing intellectual property (IP) rights abroad is not easy - not least because international IP treaties do not create global rights that can invoked in national courts. International investment law offers potential routes for overcoming these hurdles. Whenever investment treaties include IP rights as an investment and allow for investor-state dispute settlement (ISDS), investors can challenge host state measures affecting their IP rights in ISDS proceedings. As this article will show, this in turn offers a unique opportunity for invoking the standards of protection under international investment agreements (IIAs) to challenge host state compliance with international IP treaties.

While challenging national IP regimes is an attractive option for right holders, these challenges potentially amount to a sea-change for the international IP regime and cause serious concern for host states. I however argue that most of the routes pursued by right holders under IIAs are unlikely to be successful. Investment protection standards such as fair and equitable treatment, umbrella clauses and most-favored nation treatment should not be construed to allow invoking alleged breaches of international IP norms in ISDS. Some IIAs however contain clauses that subject expropriation claims against compulsory licenses and other IP limitations to a test of consistency with the international IP rules governing these limitations. As they offer the only feasible route for investors to challenge host state compliance with international IP treaties, I review the implications of these clauses, recent reform proposals and suggest alternative mechanisms for aligning international IP and investment protection based on general international law.
\end{abstract}




\section{INTRODUCTION}

The protection of IP rights via international investment agreements (IIAs) has been the subject of considerable scholarly interest in recent years. ${ }^{1}$ Most IIAs cover IP rights as a form of investment and commonly allow investors to directly challenge host state measures in investorstate dispute settlement (ISDS). As a result, several high-profile investment cases have arisen where right holders invoke protections under IIAs to challenge measures by host states that affect their IP rights in these states.

The cases ultimately indicate a unique opportunity for plaintiffs to invoke protections granted under IIAs to challenge host state compliance with international IP treaties. Generally, private right holders have no standing in fora where states can adjudicate compliance with international IP norms (such as the WTO dispute settlement system). Furthermore, domestic courts seldom allow right holders to invoke international IP norms directly or even to challenge a domestic IP provision as inconsistent with the forum state's international IP obligations, such as those under the WTO Agreement on Trade Related Aspects of Intellectual Property Rights (TRIPS). ${ }^{2}$ In the high-profile cases discussed below, right holders have attempted to circumvent these restrictions by utilising protections under IIAs to allege various breaches of international IP treaties.

Against this background, this Article reviews the various routes pursued by right holders to challenge host state compliance with its international IP treaty obligations in ISDS. My conclusion is that most challenges are unlikely to be successful. Investment protection standards such as fair and equitable treatment, umbrella clauses and most-favored nation treatment should not and have not been construed to allow invoking alleged breaches of international IP norms in ISDS. The article moves to examine specific clauses in some IIAs that ostensibly safeguard the most common forms of state interferences with IP rights (such as compulsory licenses and revocations) from expropriation challenges. It shows that by subjecting these interferences to a test of consistency with the relevant international IP

\footnotetext{
* King's College, University of Cambridge and Max Planck Institute for Innovation and Competition, Munich. An early version of this paper had been presented at the Society of International Economic Law biannual Conference in Berne, Switzerland and a revised version at a workshop on IP and investment law at King's College, Cambridge. I thank the reviewers of my manuscript and all workshop participants for their comments. All errors remain mine.

${ }^{1}$ See for example Simon Klopschinski, Der Schutz geistigen Eigentums durch völkerrechtliche Investitionsschutzverträge (Carl Heymanns Verlag, 2011); Bryan Mercurio, Awaking the Sleeping Giant: Intellectual Property Rights in International Investment Agreements, Journal of International Economic Law Vol.15 No.3, 871-915 (2012); Tania Voon, Andrew Mitchell \& James Munro, 'Intellectual Property Rights in International Investment Agreements: Striving for Coherence in National and International Law', International Economic Law after the Global Crises, edited by Chin Lim \& Bryan Mercurio (Cambridge University Press, 2014), 384; Henning Grosse Ruse-Khan, Investment Law and Intellectual Property Rights, in M Bungenberg, J Griebel, S Hobe, A Reinisch, International Investment Law - A Handbook (Beck, Hart, Nomos, 2015), 16921714 (with further references).

${ }^{2}$ For the approach in the EU see for example M Miller, TRIPS Agreement and Direct Effect in European Community Law: You Can Look...But Can You Touch, 74 Notre Dame L. Rev. (1999), 597; for an Indian perspective see the decision of the Madras High Court, Judgment of August, 8 2007, Novartis AG v. Union of India.
} 
standards, these 'safeguard clauses' offer the only feasible route for investors to challenge host state compliance with their international IP obligations. The article then in a third step assesses the implications of these clauses in light of Eli Lilly's complaint against Canada and highlights the significant changes to the dynamics of the international IP system should right holders be successful and have national IP law reviewed for its compliance with TRIPS or other IP treaties. Because of these implications, the article looks at recent reform proposals for such clauses and proposes alternative mechanisms for aligning international IP and investment protection that are based on general international law.

Following this introduction, Section II frames the nature of the problem by examining the cases where investors have invoked breaches of international IP norms in ISDS. It offers an overview on the arguments made by right holders to this effect and thereby indicates what routes, from amongst the standards of protection available under the relevant IIAs, have been employed to challenge host state compliance with IP treaties such as the WTO TRIPS Agreement, the Paris Convention for the Protection of Industrial Property (PC), the Patent Cooperation Treaty (PCT) and Chapter 17 of the North American Free Trade Agreement (NAFTA). It also considers the so far only decided case that is publicly available where an investor had invoked a breach of an international IP treaty, but eventually failed. Contrasting this decision from arguments made in the other cases, this Section concludes which routes for invoking international IP norms deserve further analysis.

Section III then assesses in detail the four routes identified in Section II and explores the merits of arguments that right holders have made or are likely to make in order to challenge host state compliance with IP treaties. These four pathways under IIAs that demand further scrutiny are: (1) the notion of protecting legitimate expectations under fair and equitable treatment (FET) and expropriation standards; (2) umbrella clauses which extend protection to other commitments of the host state in relation to the investment; (3) the most favoured nation (MFN) principle where investors could claim protection under international IP treaties as a 'more favourable treatment' of their investments; (4) and finally clauses which aim to safeguard accepted limits to IP rights in international treaties against claims of expropriation (safeguard clauses). The analysis reveals a certain irony in that these clauses - by subjecting these limits to a test of consistency with the corresponding international IP standards - effectively offer the only promising route to 'import' international IP norms into ISDS proceedings. They hence are at the focus of this Article.

Based on the conclusion that most of the routes examined generally do not allow foreign investors to successfully rely on international IP norms in investment disputes, Section III goes on to take a closer look at the law and policy implications of 'safeguard clauses' as the only promising route. These clauses raise a range of legal questions about their effects on determining the burden of proof for a breach of international IP norms, the appropriate interpretative context to assess such a breach and the scope of a consistency test when applied in ISDS. In practice, they also are likely to have profound policy implications for the ability of states to rely on the flexibilities within the international IP system - flexibilities that have been highlighted by many for their importance in pursuing domestic public policy goals such as 
access to medicines and food. ${ }^{3}$ In light of these implications, Section III finally examines recent attempts to modify safeguard clauses in IIA negotiations. Section IV then concludes the Article by offering alternatives to integrate external norms based on general international law doctrines that allow a sufficient degree of 'integration' of international IP norms within the international investment protection - but without disrupting the carefully negotiated balance between international harmonization and domestic flexibility in the international IP system.

\section{CASES INVOKING BREACHES OF INTERNATIONAL IP NORMS IN ISDS}

For long, the practical relevance of the IP and investment law overlap - caused by the incorporation of IP rights as a form of investment that is covered by most IIAs ${ }^{4}-$ seemed negligible. In recent years however, several high-profile cases have emerged where right holders rely on international investment protection to challenge various host state measures affecting IP rights. In the three most contested and publicly visible disputes, the measures challenged implement, directly or indirectly, important policy choices of the host state to protect public interests such as reducing tobacco consumption (by limiting the way logos and brand names can appear on packaging) or promoting access to medicines (by applying strict patentability requirements that often affect pharmaceutical products). This section offers an overview how, in all of these cases, international investment protections are invoked to challenge these measures as in breach of international IP treaties. This reveals a trend whose implications are further reviewed in the following Sections. This Section however also looks at the so far only ISDS Award where a decision has been reached on claims of a breach of an international IP treaty: In AHS vs Niger, this claim has been rejected. It is therefore useful to contrast the arguments for rejecting this claim with the arguments raised in the three ongoing cases. On this basis, this Section concludes which kind of routes for invoking breaches of international IP treaties deserve further scrutiny in Section III.

\section{Plain Packaging Challenges in Philip Morris vs Uruguay and Philip Morris Asia vs Australia}

Two of the pivotal cases involve the tobacco company Philip Morris and its on-going battle against various attempts to limit the use of attractive logos, brands and other get-up on tobacco

\footnotetext{
${ }^{3}$ See the WTO Ministerial Doha Declaration on the TRIPS Agreement and Public Health (Doha Declaration) (Doha, 14 November 2001, WT/MIN(01)/DEC/2); and for the UN, for example UN Economic and Social Council, 'The Impact of the Agreement on Trade Related Aspects of Intellectual Property Rights on Human Rights - Report of the High Commissioner', (27 June 2001, E/CN.4/Sub.2/2001/13), as well as United Nations - Human Rights Council, 'Report of the Special Rapporteur on the right of everyone to the enjoyment of the highest attainable standard of physical and mental health' (31 March 2009, A/HRC/11/12) paras.68-93, 108. ${ }^{4}$ For a comprehensive study on how BITs cover IP rights as protected investment see Rachel Lavery, 'Coverage of Intellectual Property Rights in International Investment Agreements: An Empirical Analysis of Definitions in a Sample of Bilateral Investment Treaties and Free Trade Agreements' 6(2) (2009) Transnational Dispute Management, pp.4-7 and Annex 1. Lavery observes that although few BITs do not explicitly address IP rights, this does not necessarily mean that they do not cover IP since BITs generally provide that the lists of covered investments are not exhaustive.
} 
packaging. In 2010, three Philip Morris (PM) companies filed a request for arbitration under the Bilateral Investment Treaty (BIT) between Uruguay and Switzerland with the International Centre for the Settlement of Investment Disputes (ICSID), ${ }^{5}$ alleging that Uruguay's limits on the use of trademarks on tobacco packaging 'have substantially damaged the value of the companies' investments in Uruguay and deprived them of the ability to use their brands and trademarks'. ${ }^{6}$ Despite the lack of publicly available filings by the parties, reports indicate that the tobacco company charges a breach of the FET standard by asserting its legitimate expectation that Uruguay complies with the TRIPS Agreement. ${ }^{7}$ Since Uruguay's limitations on the use of trademarks on tobacco packages violate the TRIPS Agreement, the argument goes, this violation frustrates PM's expectation that Uruguay would comply with TRIPS and hence amounts to a breach of FET. In essence, PM uses the ISDS vehicle to litigate compliance with international IP provisions. After a July 2013 decision on jurisdiction where Uruguay's objections had been rejected, ${ }^{8}$ the case is proceeding on the merits.

Meanwhile, in 2011, Australia introduced its Tobacco Plain Packaging Bill. The bill had two relevant provisions: First, it requires tobacco product packaging to be in drab dark brown or other prescribed colour; and second, it prohibits the use of graphic trademarks and restricts the use of word marks on tobacco product packaging to the effect that the brand, business, company or variant name may be displayed only in certain standard styles and positioning on the packaging. ${ }^{9}$ The idea behind these rules is to reduce the attractiveness and appeal of tobacco products to consumers, increase the noticeability and effectiveness of mandated health warnings, and reduce the ability of the tobacco product and its packaging to mislead consumers about the harms of smoking.

In response, Philip Morris Asia (PMA), based in Hong Kong, initiated ISDS proceedings against the Australian Government under the Hong-Kong-Australia BIT. PMA argues that plain packaging turns tobacco products into a commodity, prevents it from distinguishing its products from competitor brands, and thereby substantially diminishes the value of PMA's investments in Australia. One of its key claims is that Australia is in breach of the BIT because plain packaging is inconsistent with international trademark rules in the Paris Convention for the Protection of Industrial Property (PC) and the TRIPS Agreement. Relying primarily on the

\footnotetext{
${ }^{5}$ Philip Morris Brand Sàrl (Switzerland), Philip Morris Products S.A. (Switzerland) and Abal Hermanos S.A. (Uruguay) v Oriental Republic of Uruguay, [2009], ICSID Case No. ARB/10/7 (Philip Morris v Uruguay).

${ }^{6}$ The two regulations challenged by PM concern an increase in the packaging space reserved for health warnings from 50 to $80 \%$ and a 'single representation requirement' that prohibits sales of more than one variation of cigarettes under a single brand name (as a response to so-called colour-coding where a particular variation of a brand suggests a 'light' product, etc). See Philip Morris International, Statement and background information regarding the company's Bilateral Investment Treaty (BIT) claim against the government of Uruguay, 5 Oct 2010, available: http://www.pmi.com/eng/media_center/company statements/pages/uruguay bit_claim.aspx.

${ }^{7}$ See Todd Weiler, Philip Morris vs. Uruguay: An Analysis of Tobacco Control Measures in the Context of International Investment Law, 28 July 2010, at 26-27.

${ }^{8}$ The tribunal rejected, inter alia, the argument that Philip Morris' business of selling tobacco products in Uruguay is not an 'investment' entitled to arbitration under Art.25 of the ICSID Convention. The tribunal argued that for an investment to contribute to the host state's economic development (as any of the other 'Salini criteria') is not a 'mandatory legal requirement', but merely pointing to the typical features of an investment. See Philip Morris v Uruguay, Decision on Jurisdiction, 2 July 2013, para.204-210.

${ }^{9}$ Australian Tobacco Plain Packaging Bill 2011, s 19, 20, 21, 36.
} 
FET standard, PMA claims a 'legitimate expectation that Australia would comply with its international trade treaty obligations', in particular under TRIPS and the PC. ${ }^{10}$ PMA has also argued that the umbrella clause in the Hong Kong-Australia BIT requires Australia to observe, as an obligation it has entered into with regard to investments of protected foreign investors, compliance with 'international obligations binding on the host state that affect the way in which property is treated in Australia'. ${ }^{11}$ According to PMA, these obligations include those deriving from international IP treaties such as TRIPS and the PC. On 17 December 2015 however, the investment tribunal rejected its jurisdiction and dismissed PMA's claims on procedural grounds. ${ }^{12}$

While this effectively ends this ISDS complaint, it is nevertheless worth further exploring the arguments made to challenge compliance with international IP norms: Several countries around the globe, such as the United Kingdom, Norway, France, New Zealand and India have been considering to introduce plain packaging or similar measures. It is very likely that measures introduced elsewhere will face a similar challenge under an applicable IIA. In light of the arguments made by PM and PMA so far, it is equally likely that such a challenge will also be based on alleged breaches of international IP norms that tobacco companies will try to 'import' into ISDS via routes such as FET and umbrella clauses.

Next to these routes that emerge directly from the arguments in the tobacco packaging disputes, there is another option: Although so far not invoked in publicly available documents, there is a possibility that a foreign investor might try to invoke a most-favoured nation (MFN) clause in an IIA to demand, from the host state, IP protection under TRIPS or other IP treaties as a form of 'more favourable treatment' for its investment: If the scope of a MFN rule is construed to cover the protection under an international IP treaty, an IP right holder might well attempt to rely on the IP standards set out in that treaty in ISDS proceedings. In the dispute against Uruguay, PM for example might try to argue that the Mercosur Protocol harmonising trademark protection establishes a right to use a trademark as a form of more favourable treatment for PM's tobacco trademarks that Uruguay must extend to PM. While such a construction of MFN faces several hurdles - not least the fact that international IP treaties generally do not grant any directly enforceable rights - MFN clauses in IIAs may nevertheless provide yet another argumentative tool for investors to invoke international IP norms in ISDS. All these routes for challenging compliance with IP treaties demand further examination that will be undertaken in Section III.

\footnotetext{
${ }^{10}$ Philip Morris Asia vs. Australia, Notice of Arbitration, 21 November 2011, at para.6.5 and 7.6-7.11.

${ }^{11}$ Ibid, at para.7.15-7.17; even prior to the decision on jurisdiction of 17 December 2015 mentioned in note 10 , this claim apparently had been dropped by PMA - most likely for the reasons discussed in Part II 2).

${ }^{12}$ See Jarrod Hepburn \& Luke Eric Peterson, Breaking: Australia prevails in arbitration with Philip Morris over tobacco plain packaging dispute, Investment Arbitration reporter, 17 December 2015. At the time of writing, neither the decision, nor the principal arguments for rejecting PMA's claims have been made public. It however appears likely that the claims have been rejected because of Australia's argument that PMA has only obtained the relevant investments in Australia when it knew very well that plain packaging was coming. Essentially, Philip Morris had been 'treaty shopping' for an IIA that offered it investment protection.
} 


\section{Patent Revocation Challenge in Eli Lilly vs Canada}

A rather different investment dispute where again compliance with IP treaties is challenged concerns the US-based pharmaceutical company Eli Lilly and the revocation of two of its patents in Canada. In November 2012, Eli Lilly initiated ISDS proceedings under Chapter 11 of NAFTA against Canada, following the invalidation of pharmaceutical patents for its drugs Strattera and Zyprexa by Canadian courts. ${ }^{13}$

At the centre of the dispute is a 'promise doctrine' whereby Canadian courts take for granted what the patent application has described as the specific useful effect of the invention and require the applicant to show adequate support for that specific utility claimed in the application: If the applicant does not provide sufficient evidence, at the time of filing, for the promised utility the court has construed from the patent claims and description, the required disclosure is insufficient to support the 'promise' and the patent granted can be revoked. ${ }^{14}$ In order to justify a patent for a new use of a known substance and one for selecting a specific element from amongst a large group of known compounds, Eli Lilly had made specific utility claims in order to differentiate these applications from earlier patents - claims which Canadian Courts held to be insufficiently supported by evidence in the patent application. ${ }^{15}$ Lilly complains that the strict patentability standards resulting from the promise doctrine, as applied by the Canadian Courts since 2005, are violating Canada's international IP obligations under NAFTA, TRIPS and the Patent Cooperation Treaty (PCT). This in turn, Lilly argues, breaches NAFTA's investment chapter since 'Canada has a positive obligation to ensure Canadian law complies with NAFTA and the PCT, consistent with the reasonable investment-backed expectations of the investor.' 16

Similar to the plain packaging disputes, the investor relies on the FET (and in this instance also on the expropriation) standard to claim a legitimate expectation that the host state complies with international IP norms. In Eli Lilly vs Canada however, a specific NAFTA clause ensures that the expropriation standard does not apply to certain IP limitations such as compulsory licenses or revocations of IP rights - as long as these limits are consistent with relevant international IP rules. ${ }^{17}$ This clause, which also occurs in a range of other IIAs, offers an additional explanation why Lilly puts so much emphasis on a breach of IP treaty norms: unless Lilly can make a case that Canada's measures violate the relevant international IP provisions, it is effectively barred from invoking protection against expropriation for its patents. That in turn would significantly limit Lilly's ability to rely on one of its strongest arguments - the

\footnotetext{
${ }^{13}$ Eli Lilly and Company vs. Canada, Notice of Intent, 7 November 2012. The Lilly arbitration and the preceding domestic litigation in Canada is discussed in more depth in the contribution by Kathy Liddell \& Michael Waibel in this Special Issue.

${ }^{14}$ For a detailed discussion of the promise doctrine see Richard Gold \& Michael Shortt, 'The Promise of the Patent in Canada and Around the World‘ 30(1) (2014) Canadian Intellectual Property Review 35, http://ssrn.com/abstract=2361146

${ }^{15}$ See Eli Lilly \& Company v Teva Canada Limited, 2011 FCA 220, affirming the earlier trial court decision (2010 FC 915) and Eli Lilly Canada v Novopharm Limited, 2012 FCA 232, again affirming the earlier trial court decision (2011 FC 1288). I am thankful for the anonymous reviewer for highlighting this point.

${ }^{16}$ Eli Lilly vs. Canada, Notice of Arbitration, para.71, 77.

${ }^{17}$ See Art.1110 (7) NAFTA, referring to the IP standards set out in Chapter 17 of NAFTA.
} 
detrimental legal and economic effect the revocation has on its patents and their exploitation. In order to keep the door open for these expropriation arguments, Eli Lilly thus first has to show a breach of Canada's IP obligations. Clauses such as Art.1110 (7) NAFTA hence serve as another 'door opener' to litigate compliance with international IP law in ISDS. As they ensure that expropriation protections do not undermine flexibilities on compulsory licenses and other limitations in the international IP order, I refer to them as safeguard clauses.

The Eli Lilly patent revocation case shows that invoking international IP norms and challenging host state compliance in ISDS is not a phenomenon specific to tobacco packaging disputes. Since this line of argumentation appears in most of the publicly available IP-related investment disputes so far, it is not at all unlikely that similar claims will be made in future cases. Before the merits of these arguments are further scrutinised in Section III, the so far only decided case involving international IP norms that has been made public will be considered. Since the arbitrators refused to rule on the issue of compliance with an IP treaty in that case, it can be usefully compared with the arguments made in the disputes discussed so far. This allows to filter out those routes for challenging compliance that have already been rejected by an investment tribunal.

\section{Unauthorised Use of Trademarks in AHS vs Niger}

On 15 July 2013, ICSID released excerpts of an award in a case relating to the termination of an airport services concession in Niger in 2010. The dispute involved aviation handling service provider MMEA, a Luxembourg-registered company, and AHS, its Nigerien subsidiary, which jointly brought a claim against Niger in March 2011. ${ }^{18}$ Under the concession, the claimants had provided airport cargo and ground services at Niamey International Airport in Niger. When authorities terminated the concession and seized the claimants' bank accounts and equipment, AHS and MMEA initiated arbitration proceedings under ICSID. ${ }^{19}$ In an award from July 2013, arbitrators considered the actions by Niger as expropriation and awarded 4.6 million Euros in compensation. ${ }^{20}$ In the arbitration, AHS and MMEA also complained about infringements of its IP rights, in form of trademarks and trade names registered with OAPI, a regional IP Organization in Francophone Africa to which Niger is a Member. The complainants alleged that the new personnel employed by the Nigerien authorities, after seizing AHS' equipment, had continued to operate airport services using uniforms with IP protected trademarks and trade names registered for the claimants until early $2011 .^{21}$

The arbitrators found the arguments of the complainants with regard to this use of IP protected subject matter as not sufficient to establish a right to compensation: One the one hand, AHS

\footnotetext{
${ }^{18}$ See the report by Investment Arbitration Reporter, Niger liable for expropriation of airport services concession, but no damages due for subsequent Misuse of Intellectual Property, 19 December 2013, - online available at http://www.iareporter.com/articles/20131219/.

19 Ibid.

${ }^{20}$ See AHS Niger and Menzies Middle East and Africa S.A. v. Republic of Niger (AHS vs Niger), ICSID Case No. ARB/11/11, Award of 15 July 2013.

${ }^{21} \mathrm{Ibid}$, at para. 150 .
} 
and MMEA asserted that the use of their trademarks and trade names violated the Bangui Agreement, ${ }^{22}$ a regional IP treaty which establishes a system of trademark protection. Crucially, while the complainants could show that Niger has ratified the Bangui Agreement, they were unable to explain how compliance with this Agreement mattered for the dispute. ${ }^{23}$ In particular, the arbitration tribunal found that AHS and MMEA had not explained how it would be competent to hear arguments about a breach of the Bangui Agreement. The tribunal noted Art.47 of Annexe III of the Bangui Agreement that allocates jurisdiction for civil actions related to trademarks to civil courts; and further identifies the competent national courts in case of criminal actions, including defences based on the invalidity of the trademark. ${ }^{24}$

Apart from the alleged breach of the Bangui Agreement, the complainants argued that the use of their trade names and trademarks deceived the users of stop-over services by creating the impression that AHS was still responsible for low quality services performed by the stop-over assistance unit after seized by Niger. ${ }^{25}$ AHS and MMEA argued that this negatively affected their reputation in Niger, relying on a service-audit performed by the company DHL in relation to the stop-over assistance unit. The arbitrators nevertheless found that AHS and MMEA were unable to show any consumer confusion between the services of the stop-over assistance unit after being seized and the services earlier provided by AHS Niger - so that no harm to reputation had been proven. ${ }^{26}$

This review of the IP aspects in AHS vs Niger reveals that the arbitrators rejected the complainants' arguments based on breaches of international IP obligations (of Niger under the Bangui Agreement), and on infringements of the trademark rights owned by AHS and MMEA. While the latter is rejected on merit (there was apparently insufficient evidence for showing consumer confusion, generally an essential element of trademark infringement), the alleged breach of an international IP treaty was rejected on jurisdictional grounds: The complainants had simply not provided any relevant arguments why compliance with the Bangui Agreement could be subject to arbitration. This points to the key difference between this case and the other disputes described above: In Lilly vs Canada and in the tobacco packaging disputes, investors have relied on various arguments and investment standards that establish grounds for linking breaches of international IP rules with the protection of foreign investments. Essentially, an investment 'hook' - such as umbrella or safeguard clauses, FET or expropriation standards or MFN - is necessary to import international IP norms into ISDS so that compliance with them may be reviewed. General references to international law as (part of) the applicable law, such as in Art.42 ICSID, are insufficient for this purpose.

\section{Connecting the Cases: A Trend towards Challenging Compliance with IP Treaties via ISDS}

\footnotetext{
${ }^{22}$ Bangui Agreement Relating to the Creation of an African Intellectual Property Organization, Constituting a Revision of the Agreement Relating to the Creation of an African and Malagasy Office of Industrial Property, Bangui (Central African Republic), March 2, 1977.

${ }^{23}$ AHS vs Niger, at para. 152.

${ }^{24}$ Ibid.

${ }^{25} \mathrm{Ibid}$, at para. 153 .

${ }^{26} \mathrm{Ibid}$, at para. 154 .
} 
The cases reviewed in this section reveal that there is a general trend to invoke international IP norms in investment disputes that involve IP rights. Various routes have been employed to challenge compliance of the host state measure at stake with IP treaties. Although the total number of publicly available challenges is few, it seems quite likely that future cases involving IP rights will also involve challenges that are primarily based on breaches of international IP norms. This is compounded by the fact that there is - compared to the number of substantive protections in IIAs - a much greater number of specific international IP obligations that result from the core multilateral treaties with almost universal membership as well as from an everincreasing amount of IP provisions in bilateral and regional free trade agreements (FTAs). Right holders will find it easy to allege a breach of such a provision - but in IP law, they lack a forum to litigate them. ISDS offers them a forum; and the broad and ambiguous protections in IIAs such as FET, MFN or umbrella clauses allow them to re-package an alleged violation of a specific IP norm as breach of an IIA protection. Taken together, this offers a truly unique and unprecedented opportunity for private right holders to challenge national IP laws in a way not seen before. For this reason, the four routes that emerge from the cases discussed require further scrutiny in Section III.

\section{ROUTES FOR CHALLENGING COMPLIANCE WITH INTERNATIONAL IP TREATIES IN ISDS}

This Section analyses in greater detail the four possible routes for invoking international IP norms in ISDS that transpire from the cases examined in Section II. These four routes are (1) claiming, under FET or expropriation standards, a legitimate expectation that the host state complies with its international IP treaty commitments; (2) relying on umbrella clauses which are argued to incorporate international IP rules as a commitment the host state has made vis-àvis the investment; (3) invoking the MFN principle to demand a 'more favourable treatment' for the investment that is argued to result from an international IP norm; and (4) utilising the consistency test in safeguard clauses to argue that a limitation covered by such a clause is not consistent with the international IP standards to which that clause refers. The core question is that this Section aims to answer is whether the invocation of international IP norms is likely to lead to a review, by an ISDS tribunal, of compliance of a host state measure with that state's obligations under applicable IP treaties.

\section{A Legitimate Expectation that the Host State Complies with International IP Treaties?}

The perhaps most prominent route chosen by investors to challenge the compliance of host state measures that affect their IP rights as being in breach of international IP norms is to rely on the concept of legitimate expectations. This contested concept is usually tied to the FET 
standard, but may also relate, in some IIAs, to the protection against expropriation. ${ }^{27}$ Subsection a) begins with a detailed scrutiny of the arguments on legitimate expectations in compliance with IP treaties that are made by investors and states in the three cases introduced in Section 2. Subsection b) then examines the guidance from WTO law and the case-law of its Appellate Body on the extent to which legitimate expectations can be claimed to emanate from the TRIPS Agreement. Integrating the findings from WTO law, Subsection c) returns to an international investment law perspective and highlights the role of the host state's domestic law as principal starting point for any legitimate expectations. This allows to develop several criteria that must be fulfilled in order for an investor to legitimately expect host state compliance with international IP norms. The section concludes that on the basis of these criteria, the outlook for Eli Lilly and Philip Morris to successfully invoke legitimate expectations in the compliance with IP treaties such as TRIPS, the PCT or NAFTA Chapter 17 appears rather bleak.

a) Reviewing the Arguments made by Investors and States

In the three core IP-related investment disputes reviewed in Section II, right holders are invoking international IP obligations of the host state as a source of their legitimate expectations. They allege breaches of these obligations which then arguably frustrate their expectation that the host state complies with these obligations. That in turn, so they claim, amounts to a violation of the FET standard. At first sight, this line of reasoning appears to offer a convenient way for any foreign investor holding IP rights in a host state that is bound by IIA with FET protections to utilize ISDS in order to challenge compliance with any international IP norms the host state is bound to. It provides the argumentative space for PM, PMA and Eli Lilly to claim, in ISDS, that Uruguay's and Australia's tobacco packaging measures and Canada's patent invalidation amount to various breaches of TRIPS, the Paris Convention, NAFTA and the PCT. Before the merits of this line of reasoning are scrutinized in Subsections b) and c), it is worth to explore the individual arguments made by the PM, PMA and Eli Lilly - as well as the rebuttals by the respective host states - in more detail.

In its claims concerning tobacco packaging against Uruguay, PM maintains:

' $[\mathrm{W}]$ hile a host state has the sovereign right to change its regulatory framework, including for the purpose of pursuing public health policies, such changes must be fair and equitable in light of the investor's legitimate expectations. By issuing Ordinance

\footnotetext{
${ }^{27}$ On the role of legitimate expectations within the FET standard see generally M Jacob \& S Schill, Fair and Equitable Treatment: Content, Practice, Method, in M Bungenberg, J Griebel, S Hobe, A Reinisch, International Investment Law - A Handbook (Beck, Hart, Nomos, 2015), 700-743. It is particularly contested whether the protection of legitimate expectations is amongst the elements that are associated with the so called 'minimum standard of treatment' which has been argued to form the minimum baseline of the FET standard; see Andrew Newcombe \& Lluis Paradell, Law and Practice of Investment Treaties (Kluwer, 2009), at 235, 279. See generally Rudolf Dolzer \& Christroph Schreuer, Principles of International Investment Law (OUP, 2008), p.133-147 and C McLachlan, L Shore \& M Weiniger, International Investment Arbitration (OUP, 2007), para.7.101-129. In its Annex setting out three factors that guide the determination of what constitutes an (indirect) expropriation, the 2012 US Model includes interference with legitimate investor expectations as one element.
} 
514 which contains both the single representation requirement and the demeaning pictograms, and Decree 287/009 setting out the excessive health warning requirement, the Respondent failed to maintain a stable and predictable regulatory framework consistent with Philip Morris' legitimate expectations. (...) Ordinance 514 and Decree 287/009 must also be considered unfair and inequitable because they are incompatible, inter alia, with Uruguay's treaty obligations under the Agreement on Trade-Related Aspects of Intellectual Property Rights (“TRIPS") as well as the Paris Convention for the Protection of Industrial Property rights (the "Paris Convention"). ${ }^{28}$

In a similar fashion, PMA had claimed that Australia's plain packaging legislation frustrates its legitimate expectations in the host state's compliance 'with international trade treaty obligations' and explains in detail how plain packaging would violate TRIPS and the PC. ${ }^{29}$

Finally, in its dispute against Canada, Eli Lilly argues:

'The Government of Canada has a positive obligation to ensure Canadian law complies with Canada's international treaty obligations, as well as the reasonable investmentbacked expectations of the investor. Lilly could not reasonably have expected that Canada's patent regime, on which its investment in the Strattera Patent was predicated, would develop in a manner that departs so markedly from Canada's international obligations.' 30

In its Memorial, Lilly further specifies the expectations it based on Canada's compliance with NAFTA's IP chapter and with the PCT: No 'reasonable investor' could have expected that Canada would develop a utility doctrine inconsistent with Chapter 17 of NAFTA - 'particularly when Canada had enacted implementing legislation that expressly required that all federal laws must be interpreted in a manner consistent with the treaty' and since 'its own Minister of Industry had acknowledged on the floor of Parliament that Canada's "ability to change [its] patent law [was] defined by [the] obligations" in Chapter 17.' Lilly views the promise doctrine as a 'dramatic and internationally wrongful departure in Canada's patent law' that is 'plainly outside the acceptable margin of change that investors must reasonably anticipate'. ${ }^{31}$

In the case of patent for the drug Strattera, Lilly further argues that it 'expected that its PCT application, the basis for the Canadian patent filing, would be sufficient to meet Canadian requirements relating to disclosure of utility' and that 'Canada would not retroactively impose additional utility disclosure requirements to invalidate the Strattera Patent'. In order to substantiate the legitimacy of this expectation, Lilly simply points to Canada's ratification of the PCT and to the relevant amendments to its Patent Act, claiming that Canada had issued regulations making clear that it would 'adhere to the PCT in its entirety'. ${ }^{32}$

This line of reasoning raises a key question at the interface between international IP and investment law: Can an investor legitimately expect that the host state complies with its

\footnotetext{
${ }^{28}$ Philip Morris v. Uruguay, Request for Arbitration, 19. Februar 2010, para.84, 85 (emphasis added).

${ }^{29}$ Philip Morris Asia vs. Australia, Notice of Arbitration, 21 November 2011, at para.6.5-6.11 and 7.6-7.11.

${ }^{30}$ Eli Lilly vs Canada, Notice of Intent, at para.95-96.

${ }^{31}$ Eli Lilly vs Canada, Claimant's Memorial, 29 September 2014, para.279.

${ }^{32} \mathrm{Ibid}$, at para. 280.
} 
international IP obligations? Effectively, this would turn treaty obligations owed to other states (with, if at all, an option for contracting states to enforce them) into a basis for investor expectations that in turn can be invoked in disputes against the host state. Without any explicit reference to such treaty obligations in an IIA, it appears difficult to assume that the IIA parties intended the FET standard to be construed in such a wide-ranging manner. Accordingly, Australia counters that claims of compliance with other treaty obligations 'are plainly outside the scope of protection of the BIT, whether as a matter of the fair and equitable treatment standard established under Article 2(2) or the "umbrella clause" in Article 2(2)', ${ }^{33}$

In the specific NAFTA context, Canada further points to the 2001 NAFTA Free Trade Commission (FTC) Note of Interpretation, clarifying that a breach of another NAFTA provision or of a separate treaty does not equate to a breach of the minimum standard of treatment under Art.1105:1. ${ }^{34}$ Hence, potential violations of NAFTA's IP chapter or the PCT as such cannot be actionable under NAFTA's version of the FET standard. Regarding alleged breaches of the PCT, the fact that this is 'strictly a procedural treaty which expressly provides that it does not prescribe substantive patent law obligations' offers another reason why the PCT cannot serve as basis for any sort of legitimate expectation regarding substantive patentability requirements such as utility or sufficiency of disclosure. ${ }^{35}$ Finally, Canada emphasises the need to protect the ability of domestic courts in developing national (IP) laws: judicial law-making by means of evolutionary interpretation cannot, in the absence of a denial of justice, be challenged as an interference with legitimate expectations. ${ }^{36}$

On balance, these counter-arguments offered by Canada and Australia raise serious questions about the merits of the reasoning employed by Philip Morris and Eli Lilly. In order to address these in a comprehensive manner that is grounded in international investment law, but also takes international IP law (in particular as incorporated into the WTO legal system) into account, the next Section adds the TRIPS' perspective on legitimate expectations. With the IP view in mind, Subsection c) then completes the analysis based on international investment law.

\section{b) The Scope of Legitimate Expectations under TRIPS}

While relying on legitimate expectations in ISDS will of course be primarily judged against whether protection standards in IIAs allow to invoke such expectations at all, the set of rules on which the investor wishes to base its expectations cannot be irrelevant. In IP-related cases where the investor claims legitimate expectations based on international IP norms, the question whether these norms at all offer a basis for such expectations arises. With regard to the idea of

\footnotetext{
${ }^{33}$ See PMA vs. Australia, Australia's response to the Notice of Arbitration, 21 December 2011.

${ }^{34}$ Eli Lilly vs Canada, Counter-Memorial of Canada, 27 January 2015, para.295 - referring to the FTC Notes of Interpretation, s. 2(3) (July 31, 2001).

${ }^{35}$ Ibid, at para.297 - pointing to Art.27:5 PCT that states: 'Nothing in this Treaty and the Regulations is intended to be construed as prescribing anything that would limit the freedom of each Contracting State to prescribe such substantive conditions of patentability as it desires (...)'.

${ }^{36}$ Ibid, para. 284-289, 295.
} 
legitimate expectations based on TRIPS provisions in particular, the WTO Appellate Body (AB) has provided useful guidance that on this matter.

In India - Patents, the AB explicitly rejected the approach of the Panel to rely on the concept legitimate or reasonable expectations that may result from TRIPS provisions as a guide to the interpretation of these provisions. ${ }^{37}$ The AB noted that in WTO law, this concept originated from non-violation complaints under Art.XXIII:1(b) GATT 1947, aiming to protect the benefits that could be legitimately expected from reciprocal tariff concessions against being negated by non-tariff barriers to trade. ${ }^{38}$ Since non-violation complaints did not (and still do not) apply to TRIPS by virtue of an (extended) moratorium under Art.64 TRIPS, the concept of legitimate expectations cannot guide the interpretation of TRIPS. ${ }^{39}$

The AB then addressed the Panel's further argument that this concept follows also from applying the customary rules of treaty interpretation, in particular the notion of good faith in Art.31 (1) VCLT. In rather blunt terms, the AB rejected this argument:

'The Panel misapplies Article 31 of the Vienna Convention. The Panel misunderstands the concept of legitimate expectations in the context of the customary rules of interpretation of public international law. The legitimate expectations of the parties to a treaty are reflected in the language of the treaty itself. The duty of a treaty interpreter is to examine the words of the treaty to determine the intentions of the parties. This should be done in accordance with the principles of treaty interpretation set out in Article 31 of the Vienna Convention. But these principles of interpretation neither require nor condone the imputation into a treaty of words that are not there or the importation into a treaty of concepts that were not intended. ${ }^{, 40}$

Although the arguments above refer to the expectations of WTO Members vis-à-vis TRIPS and whether such expectations guide the interpretation of TRIPS in WTO dispute settlement, they do have relevance for investor's claims in ISDS. The AB plainly rejects the idea that legitimate expectations follow from or guide the interpretation of TRIPS - unless such expectations 'are reflected in the language of the treaty itself'. If not even WTO Members as principal addressees can generally derive legitimate expectations from TRIPS rules, how should this be possible for private parties which are at best indirect beneficiaries of IP protection under TRIPS?

On the other hand, in international investment law, the FET standard itself is the vehicle that introduces the (contested) concept of legitimate expectations. Once an ISDS tribunal accepts this concept as part of the applicable law, TRIPS (or any other international IP norm) could be seen as merely the object, but not the source of legitimate expectations. Nevertheless, claiming legitimate expectations in compliance with TRIPS essentially serves the principal purpose to litigate alleged breaches of TRIPS in ISDS. Accepting such claims effectively provides the

\footnotetext{
${ }^{37}$ India - Patent Protection for Pharmaceutical and Agricultural Chemical Products (India-Patents), Appellate Body Report, WT/DS50/AB/R (19 December 1997), para.33-42.

${ }^{38}$ Ibid, at para.41.

${ }^{39} \mathrm{Ibid}$, at para. 42 .

${ }^{40} \mathrm{Ibid}$, at para.45 (emphasis in the original).
} 
investor with a forum where his claimed expectation of what TRIPS obliges the host state to do is reviewed. In its result, this is not different from accepting legitimate expectations based on TRIPS provisions - something which the AB explicitly rejects.

These considerations militate against considering investor expectations in host state compliance with TRIPS obligations as legitimate. Even a more limited argument that the interpretation of the FET standard under Art.31 (3) c) VCLT must be guided by TRIPS as a set of rules applicable between the IIA parties ${ }^{41}$ does not provide strong support for TRIPS obligations as basis for investor expectations: Such an argument must be aligned with the exclusive jurisdiction of WTO dispute settlement in deciding over breaches of WTO law. ${ }^{42}$ Arguably, Art.23 DSU equally forms part of the interpretative context under Art.31 (3) c) VCLT. ${ }^{43}$ The notion of systemic integration hence does not support claims that an investor can legitimately expect compliance with WTO law, including TRIPS. As TRIPS itself cannot be construed to convey legitimate expectations beyond those which are 'reflected in the language of the treaty itself ${ }^{\text {' }}$, there is no general support for deriving such expectations from TRIPS (or the other international IP treaties that are integrated into TRIPS by reference). Whether those international IP norms that are at stake in the disputes reviewed here actually do convey any legitimate expectations to private parties that then could be invoked via FET, will be examined in more detail in the next Section.

On a systemic level, these considerations indicate the complex interplay between international investment and international IP law - and the distinct mechanisms for adjudication these systems employ. They also point to possibly different outcomes, depending on whose perspective is taken. In the words of the Report of the International Law Commission (ILC) on Fragmentation: 'Answers to the question depend on who you ask, what rule system is your focus on. ${ }^{45}$ In line with the overall focus of this article, the following Section undertakes a closer scrutiny from the perspective of international investment law and FET-based options for litigating compliance with international IP norms. In order to paint a more holistic picture, it however integrates the views from the international IP system that follow from this Section.

\section{c) The Role of the Host State's Domestic Legal Environment}

In international investment law, the necessary starting point for any legitimate expectations of the investor forms the domestic law and business environment of the host state. ${ }^{46}$ This is

\footnotetext{
${ }^{41}$ See Gaetan Verhoosel, The Use of Investor-State Arbitration under Bilateral Investment Treaties to Seek Relief for Breaches of WTO Law, 6(2) (2003) Journal of International Economic Law, 493, at 503-506.

${ }^{42}$ Art.23 (1) DSU states: "When Members seek the redress of a violation of obligations or other nullification or impairment of benefits under the covered agreements or an impediment to the attainment of any objective of the covered agreements, they shall have recourse to, and abide by, the rules and procedures of this Understanding."

${ }^{43}$ Klopschinski, note 1 , at 368-369.

${ }^{44}$ India-Patents, note 43, at para.45.

45 International Law Commission, Fragmentation of International Law: Difficulties Arising From the Diversification and Expansion of International Law (U.N. Doc A/CN.4/L.682), 13 April 2006 , at 245.

${ }^{46}$ See McLachlan, Shore \& Weiniger, note 29, para.7.105-107; Newcombe \& Paradell, note 29, at 286.
} 
particularly true for IP rights which, even in an age of significant international harmonization, remain in principle territorial grants based on national laws. ${ }^{47}$ International law does not create property rights autonomous from the domestic legal order - regardless how detailed and specific treaty rules on IP protected subject matter, the scope of IP protection or the exclusive rights to be granted to the right holder are. ${ }^{48}$ Furthermore, a majority of countries do not give direct effect to provisions of TRIPS, the Paris- or Berne Convention - but rather reserve for themselves the discretion for appropriately implementing them in their legal system. ${ }^{49}$ Even where the national constitutional set-up allows the direct application of international norms, only some IP treaty provisions, such as aspects of the priority rights under Art.4 of the Paris Convention, are sufficiently concrete and provide for executable rights for right holders. ${ }^{50}$ Instead, most international IP norms - including those which are at the core of the allegations of treaty violations made by PMA and Lilly - are construed in a way that they can hardly be operationalised in a domestic law setting and invoked by an individual right holder.

How, for example, should the NAFTA requirement for patents to be available for inventions that are 'useful' or 'industrially applicable' be given direct effect so that Eli Lilly can base any expectations on it? Without more, this provision says little, if anything, about the legality of a 'promise doctrine'. And how can the obligation in Art.20 TRIPS not to encumber the use of a trademark in a way that is 'unjustifiable' be directly applied to the limits imposed on PMA's trademarks by Australia's plain packaging? The concept of justifiability embodies policy space for normative considerations and domestic value judgements that are - within the limits of accepted principles of treaty interpretation - up to the implementing WTO Member to make. ${ }^{51}$ These examples indicate that successfully invoking international IP norms in ISDS involves passing several hurdles. Only in exceptional situations where the domestic law (1) allows for the direct effect of an international IP rule (2) providing individual rights that can be executed without the need for concrete domestic implementation, right holders may, in principle, rely on an international IP rule.

If these conditions are cumulatively fulfilled, an investor who benefits from such a rule may be able to claim a legitimate expectation that the host state complies with it. In light of the flexibilities and policy space international IP treaties often allow for contracting states in their domestic implementation, the notion of 'compliance' however may leave quite some discretion

\footnotetext{
${ }^{47}$ Exceptions are unitary rights created on a regional basis, such as the Community Trademark, Design or Plant Variety rights in the EU.

${ }^{48}$ See for example the approach taken by the ECHR in relation to the right to property applied to IP rights in Anheuser Busch Inc. vs. Portugal, Judgement of the Grand Chamber, 11 January 2007 (Application No 73049/01); generally see Monique Sasson, Substantive Law in Investment Treaty Arbitration: The Unsettled Relationship between International and Municipal Law, Kluwer Law International (2010), at 66 and for IP rights in particular, Grosse Ruse - Khan, note 1, at 1695-1699.

${ }^{49}$ Next to the references in note 3 see generally Hélène Ruiz Fabri, Is There a Case - Legally and Politically for Direct Effect of WTO Obligations? EJIL, Vol.25 No.1 (2014), 151-173.

${ }^{50}$ See the discussion in G H C Bodenhausen, The Paris Convention for the Protection of Industrial Property (1968), at 10-16.

${ }^{51}$ See Justin Malbon, Charles Lawson \& Mark Davison, The WTO Agreement on Trade Related Aspects of Intellectual Property Rights - A Commentary (EE 2014), 319-321; C Correa, Trade Related Aspects of Intellectual Property Rights (OUP 2007), at 200.
} 
to the host state. Domestic implementation usually will be context-specific so that the international norm as such merely offers a loose framework within which the investor may expect a country to act. In China - IPRs for example, the Panel held that whether certain IP infringements occur on a 'commercial scale' (so as to trigger the obligation in Art.61 TRIPS to provide for criminal law sanctions) depends on the 'extent of typical or usual commercial activity with respect to a given product in a given market' ${ }^{52}$ The US lost its complaint about a breach of Art.61 as it did not offer sufficient evidence that for a specific product on the Chinese market, China had failed to criminalise IP infringing activities that were on a commercial scale. A flexible reading of international IP norms where states are allowed to choose from the range of possible interpretations and implement those which suit the domestic socio-economic environment thereby places further emphasis on the domestic implementation as basis for any investor expectations.

Subjecting legitimate expectations to the wider socio-economic and legal context of the host state $^{53}$ - here primarily in form of the domestic IP law, as interpreted and applied by its courts - has yet another implication. Based on the host state's right to regulate, ${ }^{54}$ an investor will have to reckon with statute-based limits to IP rights as well as court doctrines that develop such limitations and adapt them to changing environments. In Saluka vs. Czech Republic, the tribunal emphasized:

'No investor may reasonably expect that the circumstances prevailing at the time the investment is made remain totally unchanged. In order to determine whether frustration of the foreign investor's expectations was justified and reasonable, the host State's legitimate right subsequently to regulate domestic matters in the public interest must be taken into consideration as well.' 55

In essence, even where legitimate expectations on the side of the investor exist, they are not protected per se - but need to be balanced against the host state's legitimate regulatory interests which in turn must be appreciated in the light of the high measure of deference that international law generally extends to the right of domestic authorities to regulate matters within their own borders. ${ }^{56}$ Any expectations based on international IP rules thus need to be balanced with the host state's right to regulate. Especially in today's environment where IP protected subject matter and the way we use it is subject to constant change, this right demands sufficient discretion to respond to such changes.

In sum, only where an international IP norm is a concrete embodiment of a directly applicable right for a foreign right holder in the host state, this norm serves as basic framework for legal protection of investor expectations. It is only then that, in the words of the WTO Appellate Body, legitimate expectations are 'reflected in the language of the treaty itself' ${ }^{57}$. In these cases, a valid expectation is further subject to the host states policy space in implementing the norm.

\footnotetext{
${ }^{52}$ China - Intellectual Property Rights (China - IPRs), Panel Report, WT/DS362/R (26 January 2009), at 7.577.

${ }^{53}$ See the discussion in Jacob \& Schill, note 29, at 726-727.

${ }^{54}$ On balancing legitimate expectations with the right to regulate see ibid, at 728 .

${ }^{55}$ Saluka Investments BV (The Netherlands) vs Czech Republic, Partial Award, 17 March 2006, at para. 305.

${ }^{56}$ SD Myers Inc vs Canada, Partial Award 13 November 2000, para. 263.

${ }^{57}$ India-Patents, note 43, at para.45.
} 
Such expectations finally have to be balanced against the right to regulate, as expressed in the IP context in various internationally accepted ways to limit the exclusivity an IP right entails.

In lights of these limits on the extent to which IP rights and their international regulation provide for legitimate investor expectations, it appears rather unlikely that either Philip Morris or Eli Lilly can claim that the tobacco packaging measures or the patent revocation decisions interfere with legitimate expectations based on the domestic or international IP system. Even if Australian, Uruguayan or Canadian Law would allow the direct applicability of TRIPS, PCT or NAFTA IP rules, none of the core provisions at stake is sufficiently concrete to convey any specific expectation an IP right holder could rely upon: Art.20 TRIPS requires that restrictions on the use of trademarks shall not be 'unjustifiable' - while Art.1709:1 NAFTA demands to make patents available for inventions which, inter alia, are 'capable of industrial application'. Both are written in general, open terms which allow flexibility and require fine-tuning in their domestic implementation. Neither of them in itself hence provides for individual rights an investor could expect the host state to comply with. And even if they would, successfully invoking them would need to be balanced against the right to regulate and to adapt domestic IP laws to a changing environment.

The number of cases where an investor can successfully invoke international IP norms under the FET standard in front of an investment tribunal hence appears rather limited. In addition, the wider interpretative context of the applicable IIA is decisive - especially in the case of NAFTA: In Grand River Enterprises Six Nations, Ltd., et al vs the United States of America, the tribunal concluded that the FET standard in NAFTA, as informed by customary international law, 'does not incorporate other legal protections that may be provided to investors or classes of investors under other sources of law' - otherwise FET would become 'a vehicle for generally litigating claims based on alleged infractions of domestic and international law'. ${ }^{58}$ This is indeed what Eli Lilly is looking for in its reliance on alleged breaches of international IP norms. And it is not least for this reason that the FET standard in general will not operate in a way that allows an IP right holder as investor to claim a legitimate expectation in the host state's compliance with international IP norms.

With regard to the most prominent route for an investor to challenge compliance with the host state's international IP obligations in ISDS, the analysis in this Section allows the conclusion that this route does not appear to be a promising one. Taking into account the territorial nature of IP rights, the way their protection is regulated via international IP treaties, and how the concept of legitimate expectations in international investment law operates, right holders will find it very difficult to convince an ISDS tribunal to review compliance with an international IP treaty.

\section{Umbrella Clauses to Import International IP Norms?}

\footnotetext{
${ }^{58}$ Grand River Enterprises Six Nations, Ltd., et al vs the United States of America (Grand River vs US), Award, 12 January 2011, para.219.
} 
Another option for challenging compliance with international IP norms in ISDS can arise under so called umbrella clauses which primarily function to import obligations of the host state visà-vis the investor and/or the protected investment from other legal sources (such as contracts with the investor) into an IIA. ${ }^{59}$ They enable the investor to claim breaches of the incorporated obligations in ISDS. Based on examples from the cases discussed in Section II, this section analyses whether umbrella clauses could be employed to import international IP norms in such a way that host state compliance with these norms would be reviewed by an ISDS tribunal.

At least in one instance, an investor has relied on such a clause to claim breaches of international IP obligations. The applicable rule in PMA vs Australia, Art.2:2 HK-AUS BIT, provides that each contracting party must 'observe any obligation it may have entered into with regard to investments of investors of the other Contracting Party'. PMA initially argued that Australia violated the umbrella clause because plain packaging is inconsistent with its obligations under TRIPS and the Paris Convention. In its Notice of Arbitration of 21 November 2011, PMA claimed that

' $[\mathrm{t}]$ his obligation is broader than specific obligations or representations made by the host state to investors from the other Contracting State. It also encompasses other international obligations binding on the host State that affect the way in which property is treated in Australia, regardless of the nationality of the owners of that property., 60 PMA considered the obligations enshrined in TRIPS and the Paris Convention as falling in that category and argued that as an owner of the affected investments, it 'is entitled to expect Australia to comply with its obligations', ${ }^{61}$

Australia's response is indicative of the issues raised when extending these clauses to obligations owed under international treaties between states:

'Even if it were correct (which it is not) that Article 2(2) could somehow be understood as extending an arbitral tribunal's jurisdiction to obligations owed by Australia to other States under various multilateral treaties, the treaties that PM Asia seeks to invoke all contain their own dispute settlement mechanisms. It is not the function of a dispute settlement provision such as that contained at Article 10 of the BIT to establish a roving jurisdiction that would enable a BIT tribunal to make a broad series of determinations that would potentially conflict with the determinations of the agreed dispute settlement bodies under the nominated multilateral treaties. This is all the more so in circumstances where such bodies enjoy exclusive jurisdiction. ${ }^{62}$

These jurisdictional limitations - expressed for example in Art.23 DSU - also affect the interpretation of the umbrella clauses in IIAs between parties both bound the relevant

\footnotetext{
${ }^{59}$ See generally Newcombe \& Paradell, note 29, at 437-479 and Anthony Sinclair, Umbrella Clauses, in M Bungenberg, J Griebel, S Hobe, A Reinisch, International Investment Law - A Handbook (Beck, Hart, Nomos, 2015), 887-958.

${ }^{60}$ PMA vs Australia, Notice of Arbitration, 21 November 2011, at para.7.16.

${ }^{61}$ Ibid, at para.7.17.

${ }^{62}$ See PMA vs. Australia, Australia's response to the Notice of Arbitration, 21 December 2011.
} 
multilateral treaties. ${ }^{63}$ A systemic interpretation of an umbrella clause as in Art.2:2 HK-AUS BIT does not allow such clauses to challenge compliance with IP treaties that have their own dispute settlement system - i.e. the TRIPS Agreement and the BC and PC obligation it incorporates.

However, also for those IP treaties - such as the WIPO Copyright Treaty - which do not have their own dispute settlement system, reliance on umbrella clauses to challenge host state compliance in ISDS is unlikely to be successful: After an extensive review of the historical origins and the existing tribunal practice, the tribunal in Eureko vs Poland concludes with regard to an umbrella clause identical to the language in Art.2:2 HK-AUS BIT:

'The plain meaning - the ordinary meaning - of a provision prescribing that a state "shall observe any obligations it may have entered into" with regard to certain foreign investments is not obscure. The phrase "shall observe" is imperative and categorical. "Any" obligations is capacious; it means not only obligations of a certain type, but "any" - that is to say, all - obligations entered into with regard to investments of investors of the other contracting Party. ${ }^{64}$

On its face, the term 'any obligation' might seem broad enough to encompass international obligations of the host state. ${ }^{65}$ However, the extensive review of the tribunal focusses solely on the question whether umbrella clauses can import investment-related obligations derived from contracts with the investor or the domestic law of the host state. ${ }^{66}$ Nothing from the concept's history or tribunal practice reviewed in Eureka vs Poland suggests that international obligations the host state owes to other states are equally covered. Recent commentary on the scope of umbrella clauses leads to the same conclusion. ${ }^{67}$ And even those which discuss the possibility of using umbrella clauses to litigate obligations under WTO law cannot point to a single decision where an investment tribunal has held a broad umbrella clause to cover obligations resulting from international agreements the host state has entered into vis-à-vis other states. ${ }^{68}$

Instead, the umbrella clause at stake in PMA vs Australia explicitly qualifies 'any obligation' as those 'entered into with regard to investments of investors'. It appears farfetched that BIT Contracting Parties intended this to mean each and every obligation that somehow affects foreign investment and how it fares in the host state. Given the number of binding international commitments states have entered into vis-à-vis another in areas such as trade and IP that have a bearing or indirect effect on foreign investments, such an understanding of umbrella clauses

\footnotetext{
${ }^{63}$ Arguably, jurisdictional limits expressed for example in Art.23 DSU are 'other relevant rules of international law applicable between the parties' (of the IIA) that affect the interpretation of the umbrella clause - see section 1.2).

${ }^{64}$ Eureko v Poland, Partial Award (Ad Hoc Arbitral Tribunal, 19 August 2005), para. 246.

${ }^{65}$ Voon, Mitchell \& Munro, note 1, at 404.

${ }^{66}$ Eureko v Poland (2005), para.244-260.

${ }^{67}$ Sinclair, note 66, at 940-947.

${ }^{68}$ As Alford observes, tribunals have interpreted broad umbrella clauses to give investors treaty rights with respect to contractual commitments and unilateral undertakings of the State embodied in municipal law - but none of the decided cases discussed by Alford concerns obligations emanating from an international agreement between sovereign states; see Roger Alford, The Convergence of International Trade and Investment Arbitration, 12 Santa Clara Journal of International Law 35 (2014), at 55-57 - online available at: http://digitalcommons.law.scu.edu/scujil/vol12/iss1/3.
} 
would allow investors to invoke basically any provision of the WTO covered Agreements or other international IP and trade treaties. Indeed, a large part of international economic law - in particular IP protection under TRIPS - serves the wider aim of facilitating foreign direct investment and hence can impact on its treatment in the host state. That however does not mean that states intended all of these obligations to be enforceable by private parties in ISDS; and it also does not support an interpretation of umbrella clauses to this effect. A mere relevance of such an obligation for the protected investment hence does not turn this obligation into one 'entered into with regard to investments of investors' ${ }^{69}$ Instead, this language suggests that the kind of obligations covered are only those where there is a specific and direct relation between the obligation of the host state and the investment of the investor: that is where the host state has 'entered into' the obligation with the objective to protect the specific investment the investor relies upon.

Next to these hermeneutical arguments, the principle underlying umbrella clauses, the notion of pacta sunt servanda, implies that these clauses primarily aim to transform contractual rights of the investor into claims justiciable under an IIA. ${ }^{70}$ Since the host state does not owe obligations under an international treaty (such as TRIPS) to the investor, the pacta sunt servanda rationale does not apply. Therefore, one may conclude that unless the specific wording of the umbrella clause suggests otherwise, these clauses will not lend themselves for importing obligations the host state owes to other states under international treaties. Investors hence generally cannot rely on such clauses to claim a breach of international IP treaties in ISDS.

This conclusion makes the outlook for Philip Morris in the remaining tobacco packaging disputes rather bleak: Neither the concept of legitimate expectations (via FET or expropriation claims), nor umbrella clauses allow investors to challenge compliance with international IP obligations of the host state. ${ }^{71}$ In trying to invoke breaches of international IP treaties, some investors (like Eli Lilly) can nevertheless try to rely on clauses such as those in Art.1110 (7) NAFTA - which at first sight rather appear to protect the host state so that IP related measures are safeguarded against expropriation challenges unless they breach international IP rules. As the next section discusses, there however is yet another route international investment law provides that investors might try to rely on in order to litigate compliance with international IP norms in ISDS.

\section{International IP Protections as More Favourable Treatment under Most-Favoured-Nation} Rules?

\footnotetext{
${ }^{69}$ See also Sinclair, note 66, at 946-947.

${ }^{70}$ Eureko v Poland, at 251. See also Newcombe \& Paradell, note 29, at 438.

${ }^{71}$ Even before the tribunal rejected its jurisdiction, PMA appeared to have dropped its claim of international (IP) law violations under the umbrella clause - perhaps because their lawyers convinced PMA that it does not have a case.
} 
Invoking the non-discrimination principle of most-favored-nation treatment (MFN) in international investment law could offer an alternative route to challenge adherence to international IP protection standards in ISDS. This section scrutinises whether an investor can rely on a MFN rule in an IIA to demand protection under an international IP treaty as a form of more favourable treatment for his IP rights. Since the TRIPS Agreement already contains a broad MFN clause for right holders of WTO Members, the practically most relevant aspect of this question is not about expanding the scope of TRIPS MFN via MFN rules in an IIA. ${ }^{72}$ Rather, it concerns the potential consequences that follow from the ability of an investor to directly invoke an IIA MFN rule in ISDS proceedings: It could enable an investor to challenge compliance of the host state with IP protection or enforcement obligations under TRIPS or TRIPS-plus FTAs by arguing that such protection must be made available to him as a more favourable treatment of his IP rights as investments.

Akin to invoking legitimate expectations or umbrella clauses in ISDS to import international IP norms, the MFN standard as another form of IIA protection could serve as vehicle to challenge compliance with these norms in a way not possible under national or international IP systems. TRIPS of course does not allow private parties to rely on its MFN or national treatment clauses in WTO dispute settlement. Neither does the national law of most countries allow private parties to invoke these clauses directly in domestic proceedings. Do IIAs offer an alternative venue here? Could for example PM rely on the MFN principle in order to demand from Uruguay IP protection in accordance with Mercosur rules on trademarks as a more favourable treatment available to investors from other Mercosur countries?

The answer has significant consequences for invoking IP obligations via ISDS: based on MFN, PM might attempt to claim that Art.11 of the Mercosur Protocol harmonising IP protection, ${ }^{73}$ whereby ' $[t]$ he registration of a trademark shall grant the owner an exclusive right of use', offers a more favourable treatment which Uruguay must provide for PM's tobacco trademarks in Uruguay. ${ }^{74}$ Since MFN can be based on treatment owed to a third party by reason of a treaty obligation, ${ }^{75}$ it might not even be necessary that such protection is actually afforded to trademark owners from other Mercosur countries. Similarly, in the Australian plain packaging dispute, PMA may have tried to rely on the MFN rule in Art.3 of the HK-AUS BIT to challenge Australia's compliance with Art.20 and other trademark protection obligations under TRIPS or TRIPS-plus FTAs (such as the US-Australia FTA) - by arguing that such protection must be made available as a more favourable treatment of its investments in form of trademarks.

\footnotetext{
${ }^{72}$ Since the TRIPS national treatment and MFN obligations in Art. 3 and 4 cover most aspects of the protection and enforcement of IP rights (see Art.1:2 and fn.3 to Art.3\&4 TRIPS), the areas of IP protection which an IIA MFN rule could cover beyond TRIPS are likely to be very limited.

${ }^{73}$ Protocol on Harmonization of Intellectual Property Norms in MERCOSUR in the Field of Trademarks, Indications of Source \& Appellations of Origin (Mercosur Decision No. 008 of 1995).

${ }^{74}$ Given the extremely contested nature of trademark rights in international law, this prima facie unequivocal statement in favour of a positive right to use a trademark (instead of a mere negative right to exclude) could, if invokable in ISDS, offer PM strong arguments against Uruguay's measures limiting the use of a trademark on tobacco packaging.

${ }^{75}$ August Reinisch, Most Favoured Nation Treatment, in M Bungenberg, J Griebel, S Hobe, A Reinisch, International Investment Law - A Handbook (Beck, Hart, Nomos, 2015), at 813-814.
} 
In essence, also this approach might allow an investor to enforce host state compliance with all international IP obligations that a state has entered into vis-à-vis other states in front of an ISDS tribunal: As soon as the obligation to protect foreign IP holders in IP treaties is construed as a more favourable treatment for foreign investors, the IIA MFN rule may oblige the host state to extend this protection to IP rights held by the investor. ${ }^{76}$ This option is not only interesting because it allows for a review of the host state's implementation of international IP treaties. It also may offer IP protection already prior to domestic implementation - by arguing that the relevant IP treaty (such as a FTA) directly provides for more favourable treatment to right holders from the contracting states.

The principal objection to such an argument lies in the fact that international IP treaties essentially contain obligations for contracting states - but generally do not provide for directly enforceable direct rights for private parties. ${ }^{77}$ There hence is usually no protection that follows from an IP treaty which could be extended to a foreign investor under a MFN clause. Even assuming that an IP treaty could offer protection in form of sufficiently concrete and direct enforceable rights in exceptional circumstances, the scope of the MFN provision in an IIA will primarily depend on the precise wording of the relevant MFN rule. Before briefly turning to the plain packaging and patent revocation disputes, a few general remarks nevertheless are warranted: In international investment scholarship and practice, there is considerable debate about the scope of MFN rules in IIAs. ${ }^{78}$ Since the decision in Maffezini vs Spain where the tribunal held the applicable MFN clause to import the more favorable dispute settlement rules of another IIA, ${ }^{79}$ other tribunals have adopted a more narrow approach. ${ }^{80}$

Voon, Mitchell \& Munro argue that, based on the differences in the subject matter covered by IP treaties and IIAs, the ejusdem generis principle prevents an application of MFN clauses in IIAs to demand compliance with IP protection obligations in specific IP treaties. ${ }^{81}$ Indeed, Art. 8 of the ILC Draft Articles on Most-Favoured-Nation Clauses confines MFN treatment to such treatment offered 'to a third State or to persons or things in the same relationship'. Further, Art.9 limits the type of rights falling under a MFN clause to those covered by 'the subject matter of the clause'; while Art.10 conditions the acquisition of a right to more favorable treatment to 'treatment within the limits of the subject matter of the clause. ${ }^{82}$ Even in Maffezini, the tribunal insisted that since an investor derives its rights solely from the basic treaty containing the MFN rule, 'the third-party treaty has to relate to the same subject matter as the basic treaty, be it the protection of foreign investments or the promotion of trade' ${ }^{83}$

\footnotetext{
${ }^{76}$ See Voon, Mitchell \& Munro, note 1, at 390-391.

${ }^{77}$ See Subsection 1 above. I am thankful to the anonymous reviewer for highlighting the nature of IP treaty norms in this context.

${ }^{78}$ For a comprehensive discussion see Stephan Schill, The Multilateralization of International Investment Law, Cambridge: Cambridge University Press, 2009; Reinisch, note 84, at 807-845.

${ }^{79}$ Emilio Agustín Maffezini $v$ The Kingdom of Spain (Decision of the Tribunal on Objections to Jurisdiction) (ICSID Arbitral Tribunal, Case No ARB/97/7, 25 January 2000).

${ }^{80}$ See McLachlan, Shore \& Weiniger, note 29, para.7.165-7.169; Newcombe \& Paradell, note 29, at 216-224.

${ }^{81}$ Voon, Mitchell \& Munro, note 1, at 391-392.

${ }^{82}$ International Law Commission, Draft Articles on Most-Favoured-Nation Clauses, in Report of the International Law Commission on its Thirtieth Session, (1978) 2 YBILC 8 (pt. 2) (UN Doc A/33/10).

${ }^{83}$ Emilio Agustín Maffezini v The Kingdom of Spain, at para.56.
} 
These limitations based on the ejusdem generis principle function as a general guiding line to delineate the scope of IIA MFN clauses when applied to international IP obligations. While the protection offered by IIAs can cover IP rights held by a foreign investor, the subject matter of these treaties is the protection of foreign investments: IP rights can receive protection to the extent they meet the requirements of a protected investment under the relevant IIA. Protection then comes in form of the traditional relative and absolute standards of international investment law. IP treaties on the other hand focus on various types of creative or inventive expressions of the human mind, define under which conditions and how these creations or inventions are to be protected under domestic law and regulate some of the limits of protection. Hence they do not cover the same subject matter, although IP protection can overlap with investment protection. Both types of treaties define their protected subject matter differently and apply distinct requirements as to their scope. Assuming that those states which negotiated the IIA would have intended its MFN clause to function as a vehicle to import a whole set of treaty standards from a distinct area of international law seems, to put it mildly, farfetched. One can therefore conclude that unless the specific MFN clause in an IIA suggests otherwise, these clauses generally do not allow a foreign investor to rely on IP protection the host state is obliged to grant by virtue of an international IP treaty to right holders from the contracting states.

This conclusion arguably would hold true in the plain packaging arbitration (should it have reached the merits phase): Under Art.3 of the HK-AUS BIT, Australia 'shall in its area subject investments or returns of [PMA] to treatment no less favourable than that which it accords to investments or returns of investors of any other state". While this clause generally refers to treatment accorded to investments - without the common qualification 'in like circumstances' (as for example under Art.1103:2 NAFTA) - this in itself is not sufficient for MFN to function as floodgate for any sort of protection Australia has committed to vis-à-vis other states under an international (IP) treaty. The same arguments that militate against a comparably expansive reading of umbrella clauses apply here as well: If Hong Kong and Australia had wished to grant its investors protection not only extending to that available for foreign investors under other IIAs, but reaching even further to all sorts of obligations owed to other states in distinct areas of international law, surely they would have made this explicit. As Australia contended in its reply to PMA's Notice of Arbitration: 'Such claims are plainly outside the scope of protection of the BIT' ${ }^{84}$ Since most of the IP protection rules which could be invoked by PMA as more favourable treatment are further subject to the exclusive dispute settlement system of the WTO, an interpretation of the BIT's MFN rule in light of Art.23 DSU as 'relevant rule of international law' under Art.31:3 c) VCLT also stands against a broad understanding.

No different outcome would result from applying Art.1103 NAFTA in Eli Lilly's patent revocation arbitration. This provision only requires MFN treatment for investors and investments of investors 'in like circumstances' and 'with respect to the establishment, acquisition, expansion, management, conduct, operation, and sale or other disposition of investments.' Apart from general ejusdem generis considerations about the NAFTA MFN

${ }^{84}$ Australia's Response to PMAs Notice of Arbitration, para.34. 
provision not extending to international IP treaties, the 'like circumstances' qualification speaks against this. In Pope \& Talbot v. Canada, the tribunal explained the meaning of 'like circumstances' in Art.1103 as context dependent and varying according to the individual facts at hand. ${ }^{85}$ Quoting an UNCTAD Report, Gibson notes that among the essential matters to be considered are "whether the two enterprises are in the same sector; the impact of policy objectives of the host country in particular fields; and the motivation behind the measure involved. ${ }^{86}$ Against this background, the protection for patent holders required under TRIPS or the PCT as such does not amount to 'like circumstances': TRIPS or the PCT rely, in the provisions relevant for Lilly, on factors that do not correspond with those decisive for the protection of its investments under NAFTA. The mere existence of an obligation to protect under TRIPS, the PCT or other international IP treaties does not amount to a more favourable standard, in like circumstances, for Lilly as investor or its investments. Most importantly, the fact that neither TRIPS, nor NAFTA Chapter 17, nor the PCT provide for direct rights for patent owners in Canada already prevents Lilly to successfully invoke the MFN standard in order to obtain protection under these IP treaties.

In sum, MFN clauses in IIAs do not offer right holders a feasible opportunity to import international IP norms as a more favourable treatment and thereby effectively have implementation and compliance with these norms reviewed in ISDS. This however does not conclude the review of options a right holder could try. As the final Subsection 4. shows, a particular type of clauses that at first sight safeguard the most common forms to limit IP rights from expropriation challenges may in fact offer the only successful route to have compliance with international IP rules reviewed in ISDS proceedings.

\section{4. 'Safeguard Clauses' Exempting Measures Consistent with International IP Law from Expropriation Claims}

In relation to the protection against expropriation under international investment law, Section II has already introduced 'safeguard clauses' in IIAs which aim to ensure that this protection does not override limits to IP rights accepted in international treaties. For example, Art.1110:7 NAFTA exempts essentially all IP related measures, including 'the issuance of compulsory licenses' and 'the revocation, limitation or creation of intellectual property rights' from expropriation claims - if such measures are consistent with NAFTA's IP provisions. Similarly, Art.6 (5) of the 2012 US Model BIT provides that 'the revocation, limitation, or creation of intellectual property rights' does not amount to expropriation - as long as it is 'consistent with the TRIPS Agreement'. In the 1990ies, the draft Multilateral Agreement on Investment (MAI) contained a comprehensive safeguard clause exempting IP-treaty consistent measures from expropriation claims. ${ }^{87}$ More recently, Art.9.7 (5) of the Transpacific Partnership Agreement

\footnotetext{
${ }^{85}$ Pope \& Talbot v. Canada, UNCITRAL Award (10 April, 2001), at 75.

${ }^{86}$ Christopher Gibson, Latent Grounds in Investor-State Arbitration: Do International Investment Agreements Provide New Means to Enforce Intellectual Property Rights?, in Yearbook on International Investment Law \& Policy (2010) 397, at 444.

${ }^{87}$ OECD, The MAI Negotiating Text (as of 24 April 1998), at 51.
} 
(TPP) excludes from expropriation protection 'the issuance of compulsory licences granted in relation to intellectual property rights in accordance with the TRIPS Agreement', as well as 'the revocation, limitation or creation' of IP rights as long as these acts are consistent with the IP Chapter in the TPP and with TRIPS. In the TPP, footnote 19 further explains that the term 'revocation' of IP rights 'includes the cancellation or nullification of those rights'; while the term 'limitation' of IP rights 'includes exceptions to those rights'.

This Section considers the legal and policy implications of such safeguard clauses with a specific emphasis on Art.1110 (7) NAFTA and its application in Eli Lilly vs Canada. It begins by assessing the legal implications of these clauses that effectively allow to review the consistency of a host state measure which falls within the scope of a safeguard clause against the relevant international IP norms referred to in that clause. This implicates the burden of proof for showing (in)consistency with the referenced international IP standards, the scope of the consistency test and the relevant interpretative context. This in turn has significant effects on the political economy of enforcing IP rights abroad - effects that have the potential to change the nature of international IP litigation. The section further looks at recent attempts to alleviate concerns resulting from the operation of safeguard clauses in Eli Lilly vs Canada.

\section{a) (Un)intended side effects}

At first sight, safeguard clauses appear as a reasonable mechanism to ensure coherence between international IP and investment treaties: As long as the arguably more specific body of international law considers a measure pertaining to its field as consistent with its (more specialised) rules, the more general standards of another area are not meant to interfere. However, these clauses effectively invite investors to challenge the required compliance of host state measures with TRIPS, NAFTA or other referenced IP treaties in ISDS. Lilly's complaint about Canada breaching various provisions of NAFTA's IP Chapter, based on the requirement for consistency with that Chapter in Art.1110 (7) NAFTA, confirm this. ${ }^{88}$ In its reply, Canada appears to accept this route for challenging consistency with international IP norms as it sets out, in almost 40 pages, to explain that its national patent law does conform with NAFTA's IP Chapter. ${ }^{89}$

This open invitation to challenge measures as inconsistent with TRIPS or NAFTA's IP Chapter may well indicate that negotiators had intended the possibility of litigating TRIPS or NAFTA consistency. ${ }^{90}$ On the other hand, Canada's arguments in the Lilly arbitration and recent modifications of these clauses in the Canada-EU Comprehensive Economic and Trade Agreement (CETA) in the wake of Lilly's challenge to Canadian patent law suggest that certainly not all states envisioned these practical implications of safeguard clauses. ${ }^{91}$ Whether

\footnotetext{
${ }^{88}$ Eli Lilly vs Canada, Claimant's Reply Memorial, 11 September 2015, pp.124-153.

${ }^{89}$ Eli Lilly vs Canada, Canada's Rejoinder Memorial, 8 December 2015, pp.58-94.

${ }^{90}$ I thank one of the anonymous reviewers for making this point.

${ }^{91}$ See Eli Lilly vs Canada, Counter-Memorial of Canada, 27 January 201, para.345, where Canada explains the rationale of Art.1110:7 NAFTA as to prevent 'the potential for abusive expropriation claims in the context of intellectual property' - citing M Kinnear, A Bjorklund and J Hannaford, Investment Disputes under NAFTA:
} 
intentional or unintentional, safeguard clauses like Art.6 (5) of the US Model BIT represent the only feasible route for investors to challenge a national measure as inconsistent with WTO IP rules. These clauses effectively allow the question of TRIPS consistency to be tested in proceedings outside the WTO dispute settlement system. In light of the exclusive jurisdiction under the WTO dispute settlement system, this raises questions about the legitimacy and acceptance of decisions on TRIPS compliance rendered by investment arbitration tribunals. ${ }^{92}$

A first question is who will decide on TRIPS or NAFTA Chapter 17 consistency once this matter arises under a safeguard clause in ISDS proceedings? From the possible options of (1) deference to the host state, (2) a referral to WTO or FTA state-to-state dispute settlement, or (3) allowing the investment tribunal to decide this matter, the latter appears the most likely option in practice. As long as there is no clear basis for a tribunal to deny its jurisdiction to decide on a clause that is essential for determining the applicability of the expropriation standard, it seems highly unlikely that arbitrators would adopt any of the alternative approaches which are discussed, de lege ferenda, in more detail in Section III. Indeed, Canada does not even raise the idea that anyone but the investment tribunal established in the Eli Lilly case could or should decide on the issue of consistency with international IP norms. ${ }^{93}$ On a more careful reading however, Canada's arguments suggest that national legislators enjoy wide discretion when implementing the broad and open terms used in Chapter 17 (such as 'utility' or 'discrimination'). ${ }^{94}$ If the tribunal would accept this approach, it would - without denying its jurisdiction to decide on the consistency issue - de facto defer the decision to interpret and implement the relevant international IP norms to the host state. This option aligns with the further alternatives discussed in Section III.

Considering that an investment tribunal is likely to take up the task of assessing the question of consistency with international IP norms, several further questions arise. An important practical matter concerns the burden of proof under safeguard clauses. In order to rely on a clause that leads to the inapplicability of the expropriation standards, the party invoking that clause needs to show that the compulsory license or other relevant IP limitation is indeed consistent with international IP law. Based on the general principle that the party invoking a rule of law has to show that its requirements are fulfilled, the host state as party relying on safeguard clauses will bear this burden of proof. This result - whereby the host state for example has to show consistency with TRIPS - however will often differ from allocating the

An Annotated Guide to NAFTA Chapter 11 (Kluwer, 2006), at 1110-57, in support. For the CETA response to the Eli Lilly arbitration, see section b) below.

${ }^{92}$ See in particular the arguments made based on Art.23 DSU in sections $1,2 \& 3$ and more generally the contribution by S Klopschinski in this Special Issue. While this exclusive jurisdiction clause does not bind private investors, any WTO Member agreeing to a BIT which allows ISDS to determine compliance of a host state measure with TRIPS may be acting in violation of Art.23:2 (a) DSU.

${ }^{93}$ Compare the Counter-Memorial of Canada, 27 January 2015, para.344-402, as well as the Canada's Rejoinder Memorial, 8 December 2015, pp.58-94, where Canada explains in detail to the tribunal why its patent law is consistent with NAFTA Chapter 17 and the PCT without ever suggesting that this matter is beyond the tribunal's jurisdiction.

${ }^{94}$ See Canada's Counter-Memorial, 27 January 2015, for example on the notion of 'utility' at para.351-352, 355-357, 362-363, and especially 365-369. The flexibility inherent in these terms is explicitly claimed in Canada's Rejoinder Memorial, 8 December 2015, at para.149. 
burden of proof in the WTO dispute settlement system where this matter will depend on the individual complaints. ${ }^{95}$ In a WTO dispute over the consistency of a compulsory license, the complaining member state must show a breach of one (or more) obligations the responding state has for example under Art.27 (1) or 31 TRIPS. ${ }^{96}$ Under safeguard clauses in IIAs however, the host state will be responsible for showing that its compulsory license is 'in accordance with the TRIPS Agreement'. ${ }^{97}$

In Eli Lilly's NAFTA Ch.11 challenge, reliance on Art.1110 (7) NAFTA requires Canada to show that its revocation of Lilly's patents complies with Art.1709 (8) NAFTA which allows NAFTA parties to 'revoke a patent only when:

(a) grounds exist that would have justified a refusal to grant the patent; or

(b) the grant of a compulsory license has not remedied the lack of exploitation of the patent.'

Essentially, Canada has to show that Lilly's patents did not meet the utility condition for patent protection under Art.1709 (1) NAFTA - or that the patents could have been refused on other grounds allowed in Art.1709 (1)-(3). ${ }^{98}$ This arguably differs from a proper allocation of the burden of proof in case the same issue arose in a state-to-state dispute under NAFTA Chapter 20: Even if one understands Art.1709 (8) NAFTA akin to a defence where the defendant generally bears the burden of showing that its requirements are met, this should merely require Canada to put forward the ground that justifies a refusal to grant the patent (here: lack of utility) - while the complaining state then would have to show that the relevant condition for patentability (here: utility of Lilly's patents) is in fact present. ${ }^{99}$ Art.1110 (7) NAFTA appears

\footnotetext{
${ }^{95}$ See for example United States - Measure Affecting Imports of Woven Wool Shirts and Blouses from India, Appellate Body Report (WT/DS33/AB/R and Corr.1, adopted 23 May 1997), at 14: 'the burden of proof rests upon the party, whether complaining or defending, who asserts the affirmative of a particular claim or defence'.

96 This follows from the general principle expressed in note 91: A WTO Member asserting that a compulsory license in the domestic law of another Member does not conform for example to the requirements of Art.31 TRIPS must prove that one or more of these requirements is not adhered to. The same would apply to alleged breaches of the non-discrimination rule in Art.27 (1) as well as other TRIPS obligations relating to the ability of a WTO Member to introduce limitations to the protection of IP rights. With regard to Art.30 TRIPS, the Panel in Canada - Patent Protection of Pharmaceutical Products (Canada - Patents), Panel Report (17 March 2000, WT/DS114/R) at 7.60, wrongly placed the burden of proving compliance the requirements Art.30 establishes for national exceptions to patent rights on the Defendant. Since however Art.30 (as well as other versions of the socalled 'three-step-test') contain obligations imposed on Members for the design of their exception provisions in national law, Art.30 is not a defence the defendant has to invoke - but akin to a minimum standard whose breach the complainant has to establish; see Matthew Kennedy, 'Blurred Lines: Reading TRIPS with GATT Glasses' 49(5) (2015) Journal of World Trade, 735, pp.745-47.

${ }^{97}$ See Art.6:5 of the 2012 US Model BIT and Art.9.7 (5) TPP.

98 In its Counter-Memorial of 27 January 2015 (at para.346-402) and in its Rejoinder Memorial of 8 December 2015 (at pp.58-94), Canada takes up this tasks and offers lengthy arguments to counter all the allegations of inconsistency with NAFTA's IP Chapter that have been put forward by Lilly. While this not necessarily needs to be understood as accepting to bear the burden of proofing consistency with international IP norms, Canada clearly seems to feel obliged to show that revoking Lilly's patent is consistent with NAFTA and the PCT because only in that way it can demonstrate that the requirements of Art.1110 (7) NAFTA are met (see for example the Counter-Memorial, at para.346-352).

${ }^{99}$ Since proving a negative (i.e. that a particular invention is not useful) is generally fraught with difficulties, a sensible approach for both Chapter 11 and Chapter 20 disputes would be to require the respondent state to indicate the ground on which it wishes to base its decision to revoke a patent. In particular in cases where this is the absence of a general requirement for granting a patent, the complaining party then needs to show that the revocation cannot be justified on this ground - i.e. that the relevant requirement for granting the patent exists.
} 
to turn this allocation of the burden of proof on its head. In sum, safeguard clauses require the host state to show consistency with international IP treaties - rather than the complainant to show a breach.

Another issue relates to the scope of the consistency analysis under safeguard clauses: Does for example a TRIPS consistency test require an isolated analysis of the provision addressing the measure at stake - for example Art.30 TRIPS regarding exceptions to patent rights? Not construing Art.30 within the wider (interpretative) context of TRIPS would prevent the operation of one of the main flexibilities all WTO Members had agreed to under para.5 of the Doha Declaration on TRIPS and Public Health:

'In applying the customary rules of interpretation of public international law, each provision of the TRIPS Agreement shall be read in the light of the object and purpose of the Agreement as expressed, in particular, in its objectives and principles.'

Especially the open meaning of terms used in Art.30 TRIPS (such as unreasonableness, or legitimacy) can be significantly influenced by the balancing objective in Art.7 TRIPS and the public interests principle under Art.8 (1) TRIPS. Even in Lilly's NAFTA challenge, Art.7 and 8 TRIPS could be applied as 'other relevant rules of international law applicable between the [NAFTA] parties' to guide the understanding of NAFTA IP provisions. ${ }^{100}$

However, the TRIPS objectives and the Doha Declaration as interpretative context are likely to feature less prominently (if at all) when a consistency analysis via a safeguard clause is warranted: While treaty interpretation by investment tribunals routinely relies on the principles embodied in Art.31-33 VCLT and hence is likely to equally consider treaty context and objective, ${ }^{101}$ these elements will nevertheless mean something different here: Since questions of TRIPS consistency are embedded in the IIA containing the safeguard clause, an arbitration tribunal will primarily rely on context and objective of the BIT or FTA as guiding its interpretation of the consistency test. ${ }^{102}$ The interpretative result thus is likely differ from the result achieved in a 'pure' WTO setting. These examples show the potential problems encountered when host states have to rely on TRIPS consistency tests in order to safeguard domestic measures implementing TRIPS flexibilities.

The discussion above indicates that the main problems of litigating international IP rules in ISDS actually do not result from an extensive interpretation of substantive standards such as MFN, FET or umbrella clauses. PM's and Lilly's claims in this regard are unlikely to successfully invoke international IP standards. Instead, it is the operation of safeguard clauses which explicitly refer to international IP norms that may lead investment tribunals to applying

\footnotetext{
${ }^{100}$ Art.31 (3) c) VCLT. See however the Award in Grand River vs US (para.71) where the tribunal did not accept any 'alteration' of IIA terms based on 'normal interpretative processes' under the VCLT.

${ }^{101}$ See generally August Reinisch, The Interpretation of International Investment Agreements, in M Bungenberg, J Griebel, S Hobe, A Reinisch, International Investment Law - A Handbook (Beck, Hart, Nomos, 2015), 372377, 383-405; Bruno Simma \& Dirk Pulkowski, International Investment Agreements and the General Body of Rules of Public International Law, in M Bungenberg, J Griebel, S Hobe, A Reinisch, International Investment Law - A Handbook (Beck, Hart, Nomos, 2015), 363. On the limits of interpretation and in particular the notion of systemic integration under Art.31. (3) c) VCLT, see however Grand River vs US, para.71.

102 On the routine reliance on object and purpose of an IIA in ISDS see Reinisch, note 110, at 396-401.
} 
and interpreting these norms. In light of the scarcity of authoritative decisions on international IP law, investment tribunals have little guidance to expect from the existing WTO case-law. For lack of a better alternative, their decisions may rather serve as de facto precedence for WTO panels. Given that investment tribunals cannot be expected to have comparable expertise in WTO law (let alone in specific IP matters), and do not have equivalent support available as for example a WTO Panel has in form of the WTO Secretariat, this prospect in itself is rather worrying. ${ }^{103}$ More worrying yet are arguments by Eli Lilly that a breach of an international IP norm referenced in a safeguard clause automatically leads to expropriation (discussed below).

The perhaps gravest concern with the effect of safeguard clauses however is not about the threats to jurisdictional exclusivity of the WTO dispute settlement system, coherence and expertise in international IP law, or a far-fetched reading of these clauses. Flynn points out that private enforcement of international IP standards via safeguard clauses is a 'rupture in the fabric of international intellectual property law' that takes away the de facto checks and balances operating under a state-to-state dispute settlement system where various factors inform decisions to litigate. ${ }^{104}$ From a host state perspective, these litigation constraints create a degree of safety from frivolous claims and extreme interpretations - which a complaining state is likely not to advance in fear that they might come back to haunt it.

In essence, denying right holders as private parties the option to invoke the minimum standards and general principles of international IP law functions as important de facto policy space. This applies especially to less-powerful states whose GDP might be just a fraction of the annual turn-over of multinational companies in key IP industries. The complaints of Philip Morris against Uruguay are a case in point. Excluding private litigation over public international law standards in IP prevents exactly the kind of arguments Eli Lilly now raises against Canada where broad concepts such as 'utility' as standard for patentability are turned into rigid rules that leave no or little flexibility in domestic implementation. This in turn poses a significant challenge to the policy space inherent in the international IP system that allows to tailor national IP systems to the domestic socio-economic environment and to adapt to dynamic developments in technology and how IP protected subject matter is used in a society. ${ }^{105}$ The ability for private investors to challenge compliance with international IP treaties in ISDS proceedings thereby has a significant effect on the political economy of cross-border IP litigation - with potential further implications for the policy space in the international IP system.

\section{b) Attempts to alleviate concerns}

The concerns discussed in the previous section, apparent in the Eli Lilly arbitration, most likely led Canada to insist on a more comprehensive safeguard clause in the CETA negotiations with the EU. There Canada proposed that protection against expropriation 'does not apply to a

\footnotetext{
${ }^{103}$ See also Mercurio, note 1 , at 914.

${ }^{104}$ Sean Flynn, How the Leaked TPP ISDS Chapter Threatens Intellectual Property Limitations and Exception, March 26, 2015 - online available at http://infojustice.org/archives/34189.

105 On these implications see further the contribution by K Liddell \& $M$ Waibel in this Special Issue.
} 
decision by a court, administrative tribunal, or other governmental intellectual property authority, limiting or creating an intellectual property right, except where the decision amounts to a denial of justice or an abuse of right'. ${ }^{106}$ The EU rejected this and suggested the following alternative: 'For greater certainty, the revocation, limitation or creation of intellectual property rights to the extent that these measures are consistent with [TRIPS] and the IPR Chapter of CETA, do not constitute expropriation. Moreover, a determination that these actions are inconsistent with the TRIPS Agreement does not establish that there has been an expropriation. ${ }^{107}$

Common to these proposals is that both expand the protection for IP-related measures from expropriation challenges. That aside, they differ significantly: Canada's proposal - apparently informed by its experience in the Lilly dispute so far - replaces international IP treaties as benchmark-test for IP-related measures with a denial of justice and abuse of rights standard. The EU retains a test of TRIPS (and CETA) consistency for excluding expropriation challenges, but makes it explicit that an inconsistency in itself does not imply expropriation. This is phrased as a mere clarification - so that nothing prevents an interpretation of existing safeguard clauses (such as Art.1110 (7) NAFTA) to the effect that finding a breach of international IP norms as such cannot amount to expropriation. Since the further requirements for a finding of expropriation (for example under Art.1110 (1) NAFTA) find no equivalent expression in international norms on IP limitations (such as Art.1709 (8) on patent revocations), a breach of an international IP norm hardly serves as a substitute for criteria commonly considered to determine (indirect) expropriations. ${ }^{108}$ Lilly's argument that any inconsistency with IP treaty norms under Art.1110 (7) NAFTA automatically leads to expropriation is further contradicted by the plain meaning of the safeguard clause which clearly states that protection against expropriation 'does not apply' to the listed IP limitations (once consistent with NAFTA Chapter 17). ${ }^{109}$

Canada's proposal on the other hand is a way of comprehensively shutting the door on the currently most feasible option for investors to litigate international IP norms in ISDS. In light of all the problems such an option brings along, it is something countries should give some serious thought. As the discussion in the next Section shows, getting rid of the side-effects of IP safeguard clauses does not mean that TRIPS and other international IP norms do not have a role to play in guiding our understanding of the often ambiguous standards of investment

\footnotetext{
${ }^{106}$ European Commission, Trade Policy Committee, EU Canada FTA Negotiations: Investment Chapter, Trade B2/CBA/cg/Ares 1151153 (C-386), 7 April 2014, at 13 (Art.X.11 - emphasis added). See also the discussion in M Schewel, EU, Canada Fail To Close CETA; Stuck Over Issue Related To Eli Lilly Case, Inside U.S. Trade, Vol. 32, No. 19, 9 May 2014.

${ }^{107}$ Ibid (emphasis added).

${ }^{108}$ For a comprehensive discussion of the indirect expropriation standard and its application to IP rights see Klopschinski, as note 1, at 405-471. For an overview on expropriation in international (investment) law see Andrew Newcombe, The Boundaries of Regulatory Expropriation in International Law, (April 2005), http://ssrn.com/abstract=703244, and August Reinisch, 'Expropriation' in The Oxford Handbook of International Investment Law, edited by Peter Muchlinski, Fredrico Ortino \& Christoph Schreuer (Oxford University Press, 2008) 407.

${ }^{109}$ See Eli Lilly vs Canada, Claimant's Reply Memorial, 11 September 2015, para.255-258. For a further discussion see also Gibson, note 95, at 461-463.
} 
protection when applied to IP rights. Instead, the proposal ensures that these clauses cannot be abused to litigate the host state's compliance with international IP norms in a forum that is certainly not the optimal one to address these issues. Most importantly, it retains the de facto policy space that follows from strictly limiting challenges of compliance with international IP norms to state-to-state dispute settlement.

At the time of writing however, the EU proposal seems to have won the day in CETA. Canada nevertheless managed to include a separate 'Declaration to Investment Chapter Article X.11 Paragraph 6' which states:

'Mindful that investor state dispute settlement tribunals (...) are not an appeal mechanism for the decisions of domestic courts, the Parties recall that the domestic courts of each Party are responsible for the determination of the existence and validity of intellectual property rights.'

This language primarily aims to ensure that host state sovereignty over the grant, denial and revocation of IP rights is not affected by ISDS tribunals second-guessing the proper application of domestic IP law. It however does not affect the TRIPS consistency test under the safeguard clause proposed by the EU. It also would not prevent ISDS challenges of national court decisions on the validity or existence of an IP right granted under national law: while an ISDS tribunal of course cannot bring back to life a patent that a Canadian Court found to be invalid, the declaration does not prevent the tribunal to award damages should such an invalidation be construed as expropriation or breach of the FET standard. In case of an expropriation challenge, a tribunal would again be invited to assess the consistency of such a court decision against international IP norms - with all the negative consequences discussed in section a) above.

Finally, India has proposed yet another alternative version of the safeguard clauses. In its draft Model Investment Treaty, ${ }^{110}$ under Art.2 (Scope and General Provisions), it suggests that

'[t]his Treaty shall not apply to' (...) the issuance of compulsory licenses granted in relation to intellectual property rights, or to the revocation, limitation or creation of intellectual property rights, to the extent that such issuance, revocation, limitation or creation is consistent with the Law of the Host State.'111

While this appears as a well-intended attempt to leave decisions on all kinds of IP matters to the domestic law, it may create an even graver problem: A plain reading of this clause would invite investors to simply claim a breach of domestic law in order to overcome this hurdle. This in turn would make any ISDS tribunal established under an IIA containing such a clause the final appeals instance for the consistency of national court and other decisions with their own domestic law: a true super-constitutional court without any democratic legitimacy. In IP matters, such a clause invites tribunals to review the 'proper' application of domestic law by

\footnotetext{
${ }^{110}$ Model Text for the Indian Bilateral Investment Treaty, online available at https://mygov.in/sites/default/files/master_image/Model20\%Text20\%for20\%the20\%Indian20\%Bilateral20\%Inv estment20\% Treaty[1].pdf

${ }^{111}$ See Art.2.6 (v) of Model Text for the Indian Bilateral Investment Treaty (emphasis added).
} 
IP offices and the courts and essentially gives ISDS tribunals the last say in construing, inter alia, domestic patent, trademark and copyright law. ${ }^{112}$

The attempts to address the law and policy implications caused by safeguard clauses show that states are waking up to the problems discussed in this section and look for alternatives. Since the core of the problem is created by providing private investors a route to challenge compliance with public international standards of IP protection, the principal solution lies in shutting this avenue down. That in turn does not necessarily negate an appropriate role for international IP norms in informing the proper construction of IIA standards in IP-related investment disputes. It would also not prevent states from relying on other means to achieve the 'safeguarding' effect of clauses like Art.1110 (7) NAFTA or Art.6 (5) of the US Model BIT. The final Section of this Article considers how general international law tools to integrate rules from one of its subsystems into another one can serve as alternatives to safeguard clauses.

\section{THE ALTERNATIVE OF GENERAL INTERNATIONAL LAW AND ITS TOOLS OF INTEGRATION}

How could an alternative model for addressing the interface between international IP and investment law look like? This Section concludes the review of various routes for litigating international IP norms in ISDS by offering a framework based on general international law as an alternative that does not involve the negative 'side effects' of safeguard clauses discussed in the previous Section. Before however, a summary on these routes allows to recapitulate the main findings and to better contrast them to the operation of the proposed general international tools.

In light of emerging disputes over IP rights as protected investments, this Article has reviewed the options for right holders to challenge compliance with international IP norms in ISDS. Most of these options are based on an expansive reading of traditional elements of the investment protection regime such as legitimate expectations under FET and expropriation standards, umbrella clauses or MFN. In my opinion, none of these attempts is likely to be successful. While generalisations are difficult in light of the primarily bilateral or regional nature of investment treaty protection that provides for ISDS, analysing the tobacco packaging cases and the patent revocation dispute reveals high hurdles for investors:

(1) Leaving jurisdictional issues about the exclusive competence of the WTO dispute settlement system to rule over breaches of TRIPS aside, an investor can only rely on an international IP rule if it is

a) directly applicable as part of the domestic law;

b) sufficiently concrete to be applied by domestic institutions; and

\footnotetext{
112 One however has to note that for complaints of expropriation, an ISDS tribunal (as under Art.14 or 15 of the draft) 'shall not have authority to review the Host State's determination of whether a Measure was taken for a public purpose or in compliance with its Law.' While this may in the end prevent ISDS tribunals to review domestic IP law in case of expropriation complaints, this would not cover complaints about breaches of any of the other standards of treatment in Art.3, 4 and 6 of the draft Model BIT.
} 
c) gives rise to individual rights of the investor. ${ }^{113}$

The expectation to comply with such a rule is further subject to policy space in its implementation and has to be balanced against the host state's right to regulate.

(2) Umbrella clauses - even if not limited to specific commitments made by host states have so far not been held as extending to obligations the host state has entered into visà-vis other states in international law. Neither the intention of the IIA state parties, nor the underlying pacta sunt servanda rationale for umbrella clauses supports an application which would allow right holders to rely on such clauses to claim a breach of international IP treaties in ISDS.

(3) Finally, also MFN rules in IIAs cannot be applied to incorporate IP protection under TRIPS or other international IP treaties as a form of 'more favourable treatment' to foreign investors. Based on the ejusdem generis principle, the differences in subject matter and standards of protection between IP and investment law stand against the inclusion of specific international IP protections via an IIA MFN rule.

It is then somewhat ironic that the most promising route for right holders to invoke breaches of international IP norms in investment disputes is based on clauses which should safeguard flexibilities in the international IP system from abusive reliance on the notion of expropriation. As Lilly's complaint about Canada's breaches of NAFTA, TRIPS and the PCT shows, the consequence of clauses like Art.1110:7 NAFTA is that consistency with international IP norms is tested in ISDS. In the context of TRIPS, this raises questions about the legitimacy and acceptance of any decisions on TRIPS compliance rendered by investment arbitration tribunals in light of the competing jurisdiction under the WTO dispute settlement system: If a similar safeguard clause existed under the HK-AUS BIT, should the plain packaging arbitrators have deferred a decision on Australia's compliance with Art.20 TRIPS to findings made by the WTO Panel? Should they rather wait until the Appellate Body has had its final say on the matter, or could they even refrain from judging on TRIPS consistency? What if on the other hand arbitrators in the patent revocation case make findings about a breach (or not) of NAFTA's IP Chapter, in particular its ambiguous standard of patent 'utility'? Could that have implications for construing the essentially identically worded TRIPS patentability standards? Would such a finding affect any future WTO or NAFTA dispute brought by, for example, the US against Canada?

The analysis above has shown that the institutional and normative framework within which a dispute is decided does matter: Next to questions of subject matter expertise and secretarial support, differences in allocating the burden of proof and determining the appropriate 'normative environment' for interpreting and applying IP provisions are likely to lead to distinct outcomes. In particular where the IP treaty (such as the PCT) ${ }^{114}$ does not have its own specific dispute settlement system, investment decisions on IP matters enjoy a de facto

\footnotetext{
${ }^{113}$ See also Klopschinski, note 1, at 368-379, 387-389. Weiler, note 9, reaches the same conclusion in relation to PM's claims based on legitimate expectations derived from TRIPS in its dispute against Uruguay.

${ }^{114}$ Under Art.59 of the PCT, states can bring a dispute over compliance with the PCT to the ICJ, subject to the rules of the ICJ Statute (in particular state-consent).
} 
precedence-setting character. Should it really be a matter of who gets to decide first or even who gets to decide at all?

A yet more interesting question is what the alternatives to the conventional safeguard clauses are. A first step appears to be clarifications along the lines of the EU sponsored rule in CETA which ensures that inconsistency with TRIPS is not sufficient to establish expropriation. One could go further and substitute - as proposed by Canada - the TRIPS consistency test with one that focuses on traditional investment standards, such as denial of justice or an abuse of right. The latter would avoid the problems linked to competing decisions on the same set of international rules. At the same time, it would not prevent investment arbitrators to have regard to international IP rules based on applicable law rules in IIAs, the lex arbitri or on general international law doctrines. As Gibson notes, several IIAs make more general reference to 'international law' or 'applicable rules of international law'; while Art.42 of the ICSID Convention provides that unless the parties agreed on the applicable law, the tribunal will apply the law of the host state 'and such rules of international law as may be applicable.' 115

These considerations point to the readily available alternatives based on general international law that I would propose as a less-disrupting framework for addressing the interface between international investment and IP law: Treaty interpretation and the concept of systemic integration offer sufficient means to achieve the aim of safeguard clauses to protect the host state against abusive expropriation claims in the IP context. TRIPS and other international IP norms usually serve as relevant interpretive context, in particular under Art.31 (3) c) VCLT: As soon as both state parties to the IIA are members of the WTO, the Paris or Berne Union, provisions of those treaties that more specifically bear upon a host state measure affecting IP rights as protected investments may be considered as 'relevant rules of international law applicable in the relations between the parties'. ${ }^{116}$ As a form of lex specialis for the protection of IPR related investments, international IP norms hence may affect the interpretation of investment standards. This can take place in particular in two situations:

(1) when determining the appropriate scope of protection based on open and ambiguous investment standards as applied to IP assets: The notion of full protection and security (FPS) for example, when applied in the context of measures taken by the host state pertaining to the enforcement of IP rights, should be understood in light of the provisions on IP enforcement in Part III of TRIPS. Here, the due diligence duty of a host state to protect an investor's IP rights against infringements that is owed under FPS should not be understood to exceed the specific IP enforcement standards applicable in relation between the IIA parties: Since the duty to protect under FPS does not involve absolute liability but a reasonable degree of care, ${ }^{117}$ the latter finds a more concrete expression in the relevant IP enforcement rules. ${ }^{118}$

\footnotetext{
${ }^{115}$ See Gibson, note 95, at 442.

${ }^{116}$ See Verhoosel, note 47, at 503-506. Canada also takes this view in its Rejoinder Memorial of 8 December 2015, at para.179-180.

${ }^{117}$ See the discussion of several tribunal decisions to this effect by Christoph Schreuer, Full Protection and Security, Journal of International Dispute Settlement, Vol.1 No.2 (2010), 353-369, at 366-376.

${ }^{118}$ For a detailed discussion on the full protection and security standard and IP rights see Henning Grosse RuseKhan, The Protection of Intellectual Property in International Law (OUP, forthcoming 2016).
} 
(2) Art.31 (3) c) VCLT can also be applied to uphold recognized flexibilities and exceptions in the international IP system and import them into international investment law: When dealing with compulsory licenses or other exceptions or limitations to IP rights, the notion of expropriation should be 'systemically integrated'119 into the more specific international IP rules and hence be generally understood as not overriding existing flexibilities in the IP system. This serves exactly the same function as the explicit safeguard clauses discussed above - without however leading to the application of the relevant international IP norms in such a way that their breach can be reviewed in ISDS. Here these norms merely form the interpretative frame and in that way guide towards an understanding of investment standards that is in line with the more specific rules of the international IP system, including its flexibilities.

General international law doctrines hence are readily available to fulfil the tasks of specific safeguard clauses - without the discussed side effects that follow from allowing investors to challenge compliance with international IP treaties in ISDS. The notion of systemic integration of course also allows investors to claim that investment standards are to be understood in light of IP norms which the investor may allege to have been breached by the host state. For example, Eli Lilly could claim that the revocation of its patents by Canadian Courts amounts to an expropriation under NAFTA Ch.11 because the latter has to be understood in light of both TRIPS and the NAFTA Ch.17 rules on patent revocation and utility as a condition for patentability. Arbitrators examining this claim would arguably also form their view on what these international IP standards entail and whether Canada's court decisions are consistent with them. That however does not mean that arbitrators are directly applying these standards and judging on Canada's compliance. Under interpretative concepts such as systemic integration, consistency with international IP norms merely feeds into the principal analysis of the expropriation standard - as one of several factors. ${ }^{120}$

The main downside of relying on general international law doctrines is the legal uncertainty that comes along with it: arbitrators may not consider IP norms as 'relevant rules' under Art.31 (3) c) VCLT, they may select other ones than those commonly referred to in safeguard clauses or may find their influence on the appropriate understanding of the investment standard not decisive, perhaps in light of other elements of treaty interpretation. It is not too hard to assess, in general terms, whether these shortcomings weigh as heavy as the negative effects of relying on traditional safeguard clauses described above. As the latter effectively allow private enforcement of international IP norms, most states may find this perspective rather worrying. Those who draft the next generation of IIAs therefore should think carefully which approach they prefer in addressing the overlap between international IP and investment rules.

To the extent however that safeguard clauses continue to apply, one way of mitigating the negative effects discussed above would be to rely on conflicts-of-law principles in addressing

\footnotetext{
${ }^{119}$ C Mclachlan (2005), 'The Principle of Systemic Integration and Article 31(1)(c) of the Vienna Convention', International and Comparative Law Quarterly Vol. 54 No. 2, 279-320.

${ }^{120}$ Next to other interpretative elements such as ordinary meaning, context and object and purpose, BITs sometimes contain a range of general factors that determine whether or not host state measures amounts to an expropriation; see for example Annex A to the 2013 US Model BIT or Art.1110:8 NAFTA.
} 
overlaps between different systems in international law: As I have argued elsewhere, ${ }^{121}$ an investment tribunal charged with judging on the TRIPS consistency may - mindful that it is applying a form of 'foreign law' - refer to notions in private international law in pleading and proving the existence and substance of a relevant international IP rule. The tribunal should then treat this as a matter of fact (rather than law) that needs to be proven by appropriate evidence. It thus should hear external experts testifying what these foreign rules mean - instead of construing them from their own perspective.

Alternatively, an investment tribunal may consider staying its proceedings and - especially in case of parallel proceedings such as in the plain packaging disputes - awaiting a final decision from the WTO dispute settlement body. Finally, the tribunal could operate a system of de facto deference to the implementation of international IP norms in the national law of the host state: Especially for broad and open terms such as utility, inventiveness, or justifiability, any implementation that is supported by ordinary meaning and context of these terms should suffice for a finding of consistency under a safeguard clause. Accepting a significant amount of discretion on the side of the host state in implementing international IP norms would further align with the policy space TRIPS offers to give effect to public interests and to balance the interests of right holders and users. ${ }^{122}$ Such deferential approaches to dealing with international IP norms should not be misunderstood as blanket scepticism about the ability of investment tribunals to apply and interpret international IP law. It is rather a call for taking the views and voices of those primarily dealing with distinct subject matter - such as IP - into account.

\footnotetext{
${ }^{121}$ See Henning Grosse Ruse - Khan, A Conflict-of-Laws Approach to Competing Rationalities in International Law: The Case of Plain Packaging between IP, Trade, Investment and Health, Journal of Private International Law, Vol.9 No.2 (2013), 309-348.

${ }^{122}$ See para.4 of the Doha Declaration, note 5, where all WTO Members agree that TRIPS 'does not and should not' prevent WTO Members from giving effect to public health. See further Art.7 TRIPS whereby such a balance is one of the principal objectives for IP protection and enforcement under TRIPS.
} 